\title{
Channels from Housing Wealth to Consumption
}

\author{
By
}

Rachel Ong, Sharon Parkinson, Beverley A. Searle, Susan J. Smith, and Gavin Wood

\begin{abstract}
This paper uses micro-data from two national panel surveys to analyse the flow of wealth from residential property onto households' balance sheets, where it is available for discretionary spending. The examples are Australia and the UK - two of the world's most entrenched nations of owner occupation, both with relatively complete mortgage markets. We focus on the early 2000s, which set the scene for an unprecedented wave of housing equity withdrawal. We consider equity released through sales and through additional borrowing. The findings show that equity extraction overall is not only (or even) a function of higher incomes, greater wealth and older age. Rather, it occurs across the life course, and is linked to pressing spending needs. We draw attention in particular to the growing social and economic significance of in situ equity borrowing - a practice whose financial buffering effects may form a short-lived prelude, rather than a sustainable alternative, to trading on or selling up
\end{abstract}

\section{Introduction}

Economists are increasingly interested in the extent to which the wider economy is sensitive to, or insulated from, elements of the housing cycle (Duca et al. 2010). One aspect of this turns on the 'wealth effects' of housing. Some question the extent to which home prices impact directly on consumption (Attanasio et al. 2005; Attanasio and Weber 2010); others debate the magnitude of housing's wealth effects relative to those of other financial assets (Bostic et al 2006; Campbell and Cocco 2007; Carroll et al. 2011; Case et al. 2005; Dvornak and Kohler 2007; Poterba, 2000). Most agree that in economies with liberal financial systems, housing's wealth effects are marked (Muellbauer 2012). Probing further, there is work on the balance of funds realized through home sales, or extracted as secured debt via a 
'collateral effect' (Ebner 2010; Greenspan and Kennedy 2007; Muellbauer and Murphy 2008; Schwartz et al. 2008). Other questions about the varied channels from housing wealth to consumption are less well explored (Holmans 2001; Holmans and Froszrega, 1997; Smith and Searle 2008), and much more is known about the link between housing wealth and the resilience of whole economies, than about the implications of these wealth effects for households' financial fortunes. This paper was conceived, in part, to bridge that empirical gap.

Sociological interest in the salience of housing assets has also blossomed of late, as attention has turned to the changing role of housing wealth and mortgage debt in households' wider welfare. This is particularly pressing in 'home-ownership' societies like the UK and Australia, where housing is the major wealth-holding for the majority of households, and mortgages account for the bulk of personal debt (Bridges et al. 2006; Wood et al. 2010b). This literature is explicitly concerned with the myriad options owner occupiers have to draw from housing wealth to meet certain spending needs through various styles of housing equity withdrawal (HEW). There are separate bodies of work on the changing role of housing wealth in inheritance (Hamnett 1991; Rowlingson and McKay 2005; Thorns 1994), on the pros and cons of equity release in older age (Ball et al. 2011, German 2012), and on the predictors of mortgage equity withdrawal (MEW) among those of working age (Parkinson et al. 2009; Wood et al. 2012). There is also growing interest in how these opportunities for equity extraction impact on the role of housing wealth as an asset base for welfare (Doling and Ronald 2010; Lowe et al. 2011; Smith et al. 2009). This paper offers an empirical benchmark for such deliberations, and attempts to accommodate them within a single framework.

Both these (economic and social) debates are inspired by the growing significance and increased fungibility of housing wealth in the run up to the recent financial crisis - a time when housing markets were liquid, regulatory regimes relaxed, mortgage contracts flexible, and credit cheap and in good supply. All this had a bearing on the width of, and relationships between, the various channels from housing wealth to consumption. This paper provides a map of that changing landscape.

To that end, we draw from the national panel surveys of Australia and the UK, for the first decade of the millennium. Australia and the UK are apposite examples, being two of the world's most entrenched nations of owner occupation, with a diverse housing stock, relatively complete mortgage markets, and a comprehensive range of options for HEW. There are institutional differences in the housing systems of the two countries, but rather more similarities in matters of financial, regulation and policy than either country has with, say, the 
USA, or indeed, with any other high home ownership jurisdiction. The unusual availability of closely comparable panel datasets is an additional spur to this exercise (as explained below).

We begin with an overview of data and methods, followed by a short account of the scope for HEW via different mechanisms or channels. The bulk of the analysis falls into two further sections. First, we focus on households' balance sheets, charting the sums extracted as HEW and assessing their implications for incomes and expenditures. Second, we look to more sociological themes, exploring the characteristics and circumstances that precipitate different styles of equity withdrawal. The findings, as anticipated, inform a range of economic debates; they also engage with the concerns of social policy.

\section{Channels of Equity Withdrawal: Data and Definitions}

The analysis draws from two nationally representative panel surveys: the British Household Panel Survey (BHPS) and the survey of Household, Income and Labour Dynamics in Australia (HILDA). These surveys are based on similar sampling designs and data collection methods, and contain large numbers of directly comparable housing variables. Such similarities are rare; they create a unique opportunity to match the inter-temporal equity withdrawal behaviour of owner-occupiers across two countries whose juxtaposition already merits attention. Behavioral patterns observed across jurisdictional boundaries carry more weight than if found in one country alone, and whether they indicate similarities or differences such findings may motivate further comparative research.

The BHPS began as a panel of approximately 5,500 households in 1991, which was boosted by regional subsamples from Scotland, Wales and Northern Ireland, embracing 10,631 households by 2001. HILDA runs from 2001 with a starting panel of 7,682 households. Both surveys track the original household members through time, and contain a record of key socio-economic, financial and attitudinal changes among respondents across their life course. The last year of the BHPS (prior to its absorption within Understanding Society) is 2008, and this paper covers the common years with HILDA, namely 2001-2008. This is an important timespan, tracking the fortunes of owner occupiers in two countries through the peak and into the downturn of a housing cycle that was distinctive for its global reach (Kim and Renaud 2009; Renaud and Kim 2007).

The analysis includes all households living in private dwellings between 2001-2008 who were home owners or buyers at any time during that period, viz: all home owners in 2001; renters who became home owners after 2001 and before the end of 2008; those who were dependent children in 2001 but later formed new owner-occupier households; partners of original sample members who joined the survey at a later wave; owner-occupiers who sold up 
and moved into non-private dwellings such as nursing home institutions between 2001 and 2008; and multi-income unit owner households.

Because BHPS and HILDA are annual panel surveys, our measures of the incidence and magnitude of HEW have a one-year accounting period. That is, each episode of equity extraction (or injection) refers to the net change over a reference year in a household's selfreported outstanding mortgage debt (together with self-reported sale and purchase values for movers, and, where appropriate, self assessed property values). Most household surveys rely on self-reported financial variables. Neither BHPS nor HILDA is an exception so there are, as might be expected, some caveats concerning data quality.

There are, for example, missing mortgage debt values in both datasets. In the BHPS, the annual incidence of non-reporting of mortgage debt by owner-occupiers ranges from $7.9 \%$ to $12.8 \%$ over the period of analysis (2001-08), or $10.4 \%$ on average. This is low in comparison with some other UK surveys (Smith and Searle 2008). In HILDA, the incidence is lower still, ranging from $2.3 \%$ to $3.9 \%$, or $2.8 \%$ on average. Some implications of these missing values are discussed in Parkinson et al. (2009), while parallel qualitative work leads us to conclude that over an annual cycle, borrowers have a good sense of whether or not their outstanding mortgage debt has increased (Smith et al. 2009).

The panel surveys also rely on self-assessed house prices. While the large size of housing transactions implies reasonably accurate recall of sale prices achieved within a year, existing studies have yet to reach consensus on whether home owners' self-reported values in the absence of sales accurately reflect the market values of their homes. Agarwal (2007), Goodman and Ittner (1992) and DiPasquale and Somerville (1995), for example, found that home owners' self-reported house values are somewhat higher than market values. On the other hand, Kennickell and Starr-McCluer (1997) and Bucks and Penns (2006) argue that most home owners report their house values accurately.

The approach in this paper also relies on matching pairs of observations across adjacent waves to calculate whether or not equity has been extracted between any two years. Waveon-wave attrition is inevitable in panel surveys. In the BHPS sample, the wave-on-wave attrition rate ranges from $7.2 \%$ to $16.5 \%$ over the period of analysis, or $9 \%$ on average. In the HILDA sample, the wave-on-wave attrition rate ranges from $7.7 \%$ to $13.8 \%$, or $9.9 \%$ on average. For our purposes, there is no reliable means of compensating for this attrition. However, to put this into context, a household who was an owner-occupier throughout the study period has, using measures designed for this study, a maximum of seven potential annual episodes of HEW. That is, there are over twenty five thousand episodes recorded for 
Australia, and almost thirty-four thousand for the UK. To identify which among these are realized, we measure three styles of equity extraction.

Traditionally, the major mechanism for HEW is the 'selling up' of whole homes to release the unmortgaged equity within them. For owners, this must occur at the end of life, in the euphemistic guise of 'last time sales'. The option actively to exit from ownership is, nevertheless, available across the life course. Indeed, because this paper focuses on equity extraction behaviours, our measure of selling up is limited to those who go on to rent. Where appropriate, and as a benchmark, we also provide estimates relating to last time sales.

To measure equity withdrawal by selling up, we thus select households living in owner occupied homes in wave $\mathrm{t}-1$, and moving into rentals in wave $\mathrm{t}$ (for last time sales, we note exit from the survey due to death in wave $\mathrm{t}$ ). The amount withdrawn is simply the housing equity held in the home that was sold. Some households move to rent without selling their previously owner occupied home (perhaps because their move is tentative or temporary). These are excluded from BHPS, as are their proxy - temporary movers - from HILDA. Where selling up is prompted by separation and divorce, we assume the outstanding equity is split evenly between the ex-partners.

HEW can also be achieved through trading on within owner-occupation. Conventionally, trading on is positioned within a housing career framework, and regarded as the key means by which home buyers move up the property ladder, rolling over their capital gains and/or increasing their mortgage to facilitate this. In practice, however, trading on embraces a variety of other behaviours. These may be neutral to equity and debt: swapping homes for the same price and the same size of mortgage, for example. Alternatively, trading on can whether the move is to a higher or lower value property - be used to engage in various combinations of equity release and MEW. For example, this tactic can be used to cash in the difference in value between one (high priced) home and the next (lower priced) purchase. In this case it would, like selling up, be a simple equity release transaction. Trading up or down may equally involve an element of MEW (where the size of the new mortgage exceeds that needed to cover the difference in value of the traded properties). So trading on offers a mix of equity release and MEW, for those who wish, are willing, or have no choice but, to move home. This is curiously under researched, even though Turner and Yang (2006) argue that it helped fund a wave of early retirements in Europe during the early years of the new millennium.

Here, our calculations of HEW through trading-on are made by first selecting households that have moved between adjacent waves, and then comparing housing equity (house value minus debt) stored in the home purchased in wave t, with that accumulated in the home sold in wave 
t-1. A decreasing housing equity position shows that households have used the move as an opportunity to withdraw equity; an increasing housing equity position shows that households have rolled over their capital gains, and possibly used other assets to pay down outstanding debt.

Finally we measure a style of MEW best described as in situ equity borrowing. We use this term to signal that the funds released are available for discretionary expenditure (including, say, reinvestment into housing, which some definitions of MEW exclude). In its more traditional form (its only form in some jurisdictions) equity borrowing involves remortgaging (or refinancing, as it is called in the USA), to use rising home prices and lower interest rates to increase outstanding secured loans without moving home. In relatively complete mortgage markets, such as those in the UK and Australia, on the other hand, many households hold contracts that allow them routinely to extend their borrowings (to pre-agreed limits).

Cheques, credit cards and cash withdrawals are added to the outstanding mortgage debt; just as wages, savings and other cash injections are used to offset previous borrowings. This means that instead of mortgages simply spreading incomes across the life course (enabling mortgagors to offset their high outlays today against the lower housing costs of outright ownership in older age), they can be used to bring forward consumption (or indeed any element of discretionary spending, for example, for debt consolidation or portfolio diversification) across any time period in the term of the mortgage (Smith et al. 2002).

Our measure of in situ equity borrowing selects households that have not moved between adjacent waves, and compares outstanding debt in waves $t$ and $t-1$. Increased mortgage debt signals in situ equity borrowing; decreased debt is termed equity saving. Where the outstanding mortgage debt is unchanged it is also interpreted as equity saving (strictly, this presumes that home values are rising, which, for much of the study period they were; however, the important point is that the label 'equity saving' marks the absence of active equity borrowing). Separation or divorce can trigger the departure of one partner while the other remains in the family home. In these circumstances the outstanding debt reported by the couple before separation/divorce in wave $\mathrm{t}-1$ is compared with that reported by the in situ partner in wave t.

The analysis herein based on the above household measures. However, an aim of the wider study is to identify a range of characteristics that enhance or depress the likelihood of equity extraction, some of which (like age) are better measured for individuals. Where such measures are required, we take them from the person (and where appropriate also their partner) identified by each survey as having primary responsibility for the household's finances. Annual episodes of equity withdrawal are then tagged to that person's (those persons') characteristics as measured in that particular year. 


\section{Setting the Scene}

We begin, in Table 1, with a map of the potential for HEW in the UK and Australia in the years 2001-8, as measured by the two surveys. This gives sample numbers (unweighted) of households who sold up (and moved into rental housing), traded on, or remained in situ during each of the years ending 2002 through 2008. Totals refer to the number of annual cycles (episodes) in the study period during which owner-occupiers (outright owners and mortgagors combined) had the opportunity to withdraw (or not withdraw) equity by one or more of the three defined channels. Unsurprisingly, the data show that most households remain at the same address between adjacent years: staying put accounts for over ninety per cent of available episodes.

[Table 1]

Among the minority who move from year to year, the common strategy is to trade on within owner occupation. This accounts for just under four per cent of cycles in each jurisdiction, and the trend is towards a slight decline across the study years. Nevertheless, it is more common than selling up - a tactic which accounts for less than one per cent of UK, and $2.5 \%$ of Australian, episodes. That this is a minority activity unsurprising, as it goes against the grain of the traditional housing career to leave home ownership once that tenure is attained. There is, however, a notable difference in the way residential relocation works in the two countries: $40 \%$ of moves in Australia, compared with just $16 \%$ in the UK, involve a tenure shift from owning to renting. This may reflect the institutional characteristics of the Australian rental sector: it is larger than that of the UK, dominated by private landlords, advantaged by tax incentives, and contains good opportunities for middle income households.

Table 2 is a map of actual HEW, which, it seems, is a common event. There are more than 5000 episodes of equity withdrawal in each jurisdiction across the study period; that is, fully one in five of the total cycles available ( $22 \%$ in Australia, $18 \%$ in the UK). Less than half the households who engage in such activity (47\% in the UK, $45 \%$ in Australia) do so just once across the seven accounting years. This means that more than one-half of the owner occupiers who withdrew equity at all are serial equity extractors; indeed, over a third withdrew equity in three or more annual cycles.

[Table 2]

Comparing the totals in table 2 with those in table 1 it is clear that residential relocation events are over-represented among episodes of equity extraction. Trading on, for example, 
accounts for less than four per cent of all episodes, but fully eight per cent of equity extraction cycles in both countries; selling up is similarly over-represented by a factor exceeding four. Trading on is a housing pathway in which equity injection (not withdrawal) is the traditional expectation, so it is notable that a high, and increasing, proportion of such moves across the study period were in practice used to release equity rather than add leverage. Prior to 2005 around a third of those who traded on also extracted equity (somewhat under one in three in the UK, somewhat over that in Australia). By the end of the study period, close to half such transactions in both countries produced a net cash gain (the figure peaked at 54\%, was attained in 2007-8 for the UK, and in 2004-5 for Australia).

The dominant message from Table 2, however, is that by far the most frequent style of equity withdrawal is that which occurs in situ. Equity borrowing of this type occurs less often than equity saving, but it dominates the equity withdrawal picture in both countries, accounting for 9 in every 10 episodes equity extraction. This dominance is not much disturbed by including equity extraction through 'last time sales'. (In the UK, last time sales account for $2.7 \%$ of all equity extraction episodes across the study years, and for $42 \%$ of all equity extractions through selling up - though we presume rather than demonstrate that the property is sold on death. In Australia the figures are lower; $2.6 \%$ and 20\%, respectively.) In situ equity borrowing is, in short, a practice whose role and significance has been somewhat neglected in relation to its prominence (Smith and Searle 2008), and we return to this below.

\section{Money matters}

Until recently, housing wealth functioned as a relatively illiquid investment for most homebuyers. As an asset, owner occupation worked more like a pension than a savings account; often it was simply rolled on to the next generation. However, such literature as there is finds that bequest motivations for the accumulation of housing wealth are declining, and that successively younger cohorts are increasingly inclined to cash in their home assets before they die (Haffner, 2008). The extent to which of this change is apparent from Figures 1 and 2, which show the median values of annual withdrawals through each channel across the study period (overall and by year) for the two jurisdictions.

\section{[Figure 1]}

Figure 1 shows that overall, as might be expected, the largest sums extracted per episode pertain to the relatively infrequent event of selling up. These sums are much higher than those realized in any other way, exceeding six times the median for equity extractions in the UK and three times that for Australia. Trading on, unsurprisingly, typically results in lower values of equity extraction than does selling up, though there are intriguing patterns of convergence 
and divergence between these channels over the study years (Figure 2). Overall, however, the median cash values extracted through both these routes more than doubled in Australia and almost tripled in the UK between 2001 and 2008.

[Figure 2]

What is perhaps surprising, given that selling up is a method of realizing the ent ire unmortgaged value of an owned home, is that the sums raised in this way are not closer to the average home prices for the period. In fact, the median sums raised through selling up are less than half the median house prices as computed from the surveys for each jurisdiction across most years, with the differential narrowing over time for the UK, and widening for Australia. This discrepancy (which does not hold for last time sales) implies either that those who sell up typically occupy properties worth much less than average, or that the majority have a significant outstanding mortgage debt to clear. The truth is a little of each. The median value of properties owned by those in the selling up group is below the median house price of all owner-occupiers in both countries in almost every year of the study. The difference is less than ten per cent in some years, but has been as large as 25\% in the UK (in 2002 and 2004) and $15 \%$ in Australia (in 2001 and 2005). Households who sell up are also more likely than those who do not to be carrying mortgage debt, especially in Australia. Over the study period, around 70 per cent of those selling up each year in Australia were carrying mortgage debt (compared with 49 per cent of all owner occupiers). The discrepancy in the UK is less but still notable: an average of $64 \%$ per year of the sellers, compared with $45 \%$ per year of all owners, were mortgagors.

The most frequently used channel for equity extraction - in situ borrowing - realizes the smallest median cash sum per episode, and shows the most consistency from year to year. What is significant here is that these sums did not drop off as the credit squeeze tightened, perhaps suggesting that these actions are by established borrowers using existing mortgage contracts, rather than (as in the US model) through serial remortgaging with a changing suite of lenders.

Table 3 uses population-weighted data to arrive at economy-wide estimates of the gross amounts withdrawn for each channel over the study years. (These weights are given for HILDA but imputed for BHPS.) These values are not directly comparable with those derived by monetary authorities from aggregate data, and are not intended to be. Measures appropriate for macroeconomic estimates of housing's wealth effects (net of funds saved or reinvested) differ substantially from those employed to capture households' discretionary spending decisions (driven by a mix of equity extraction behaviours). One striking figure from the household data is, nevertheless, the high gross value of HEW across the study 
period: an average of $£ 80 \mathrm{bn}$ and $\$ A u 77 \mathrm{bn}$ per year (gross figures that, for the UK, are about $£ 20$ bn pa higher than the Bank of England's estimates of HEW net of transactions costs and reinvestment). If last time sales are included, the figures rise to $£ 90.9$ and \$AU84.3. More salient still is the fact that the aggregate value of in situ equity borrowing far exceeds that of all the other channels in every annual cycle. This mechanism accounts overall for as much as two thirds of the total flow of funds from housing into the cash economy. The annual values of these equity borrowings held steady over the years, increased by more than fifty per cent across the study period and show only a slight dip (and only in the UK) with the onset of the global financial crisis. On the other hand, in the UK (in contrast to Australia where house prices have been more resilient) the sums raised through trading on more than halved, and those raised through selling up diminished by more than two-thirds, between 2005-6 and 2007-8. When economies slow down uneven impacts across channels is to be expected. The selling up and trading on channels dry up as house prices stagnate. However, as monetary policy is eased and interest rates fall in response to downturns, equity borrowing is supported.

[Figure 3]

As a footnote to this, it is worth adding that (even without last time sales) more cash was extracted as HEW during the study period than was injected through a mix of mortgage repayments and trading up. The difference across the whole study period is $£ 78 \mathrm{~b}$ and \$Au158bn. The annual pattern is shown in figure 3. If there is a trend it is toward divergence: equity extraction increasingly exceeds equity injection as average annual growth in equity extraction (at $8 \%$ and $10 \%$ for UK and Australia, respectively) surpasses average growth rates for equity injection (3\% and 1\%) in both nations. The question this raises is how far the aggregate pattern plays out for households. Do equity injection and withdrawal cancel one another out for some households, and diverge markedly for others; are there systematic differences between households that are serial net equity extractors and serial equity savers; and what are the implications of this?

To preface some answers, Table 4 shows that for all channels combined, the total value of HEW across the early years of the present century represent an astonishing addition to households' spending power.

[Table 4]

Among those who withdrew any equity at all in this period, the amount typically released increased median household incomes by over a quarter (29\%) in the UK. In Australia, the pattern is even more dramatic: here, the combined value of all equity withdrawal episodes raised incomes by nearly fifty per cent. Very substantial income multiples are accrued 
through selling up, as might be expected: in a typical year, the median UK selling-up episode tripled the annual income of the median seller; in Australia the effect was to more than double incomes. Trading on can also release sufficient funds to double or triple the median annual income: a fact which might be more surprising still, given the presumption that so much of this behaviour is geared to trading up. Interestingly, at least 2 in 5 of those who release equity whilst trading on did so whilst buying a higher priced home, that is, they were both trading up and equity downsizing on the back of rising property prices.

More striking still is a finding that the very widespread event of in situ equity borrowing typically increases households' incomes by nearly a quarter in the UK, and over a third in Australia. These sums are not trivial, and they are extracted for no other reason than to supplement incomes (whether to clear other debts, repair or renovate homes, bring consumption forward, or meet pressing spending needs). The significance of this is underlined by the fact that, in every year, and to an increasing extent, equity extractions as a proportion of extractors' incomes, exceeded equity injections as a proportion of injectors' incomes.

Adding a macro-economic perspective, Table 5 shows that, in aggregate, HEW added more than ten per cent to total household incomes (on average in any one year) in both the UK and Australia. The majority of this occurred through in situ equity borrowing. This substantial addition to the financial resources of the personal sector is maintained across the study period, offering a powerful measure of the potential importance of these under-explored behaviours to the whole economy. Against that background, we turn next to the vexed question of how HEW fits into households spending needs and wider wellbeing.

[Table 5]

\section{A sociology of housing finance}

Far too little is known about the attitudes, beliefs and behaviours that underpin HEW. This paper cannot fill those gaps, but it does offer some preliminary ideas based on an overview of who is involved and which behaviours they engage in.

Figure 4 gives the median incomes of the households involved in each episode of equity withdrawal. Note that the values are given in Australian dollars and British pounds, as appropriate. Using a common currency would better enable cross-country comparison of real income levels, but this would involve the arbitrary selection of an annual exchange rate perhaps compromising the main aim of the figure, which is to compare the ranking of incomes across equity extraction channels. In both the UK and Australia those who release 
equity by selling up have incomes that are substantially below average among equity extractors, and somewhat lower than those of equity savers. In situ equity borrowers, on the other hand, have above average incomes, substantially exceeding those of equity savers (by over $40 \%$ in an average year in both countries). Those who release equity by trading on sit somewhere in the middle: their incomes on average are closest to those of equity savers. The indication here is that those who release equity by borrowing up do so on the back of reasonable and sustained incomes; those whose incomes are lower may need to trade on or sell up in order to secure the liquidity they need.

[Figure 4]

Figures 5, 6 and 7 amplify this finding, for the UK and Australia respectively. These figures are based on the distribution of episodes of equity withdrawal across households with different characteristics. They show the difference between the sample percentage of extraction cycles using a particular channel, and a subgroup's percentage of extraction cycles using that same channel. We have also modeled these data, and present the more technical findings as Appendix A. The patterns are rather similar between jurisdictions. The modeling exercise adds a few qualifications (which are noted in the text) to the more accessible charts provided below.

\section{[Figure 5]}

Equity extraction through selling up is disproportionately engaged in by households who are older (75+), widowed or separated. Each of these groups accounts for between 10 and 30 percentage points more cycles of equity withdrawal than average. Divorce also substantially raises the odds of selling up, compared to being married. The age effect is in line with the conventional wisdom, underpinned by a life cycle approach to savings and wealth (Ando and Modigliani 1963); these findings also reflect newer understandings of the impact of separation on housing pathways (Wood and Nygaard 2010; Wood et al. 2010b).

More surprising is the indication in Figure 5 that younger, single person households are also over-represented among those who sell up in order to extract home equity. In both countries the under-25s are three times as likely as the average equity extractor to use this option. Exiting ownership is contrary to expectations in housing systems dominated by owner occupation, though it is in line with the growing conviction that there is unsustainable financial stress at the edges of home ownership. At the very least it suggests those who extract equity by selling up do so as much to 'bring forward' their spending as to bolster older age. This, after all, is the equity extraction channel used by those whose incomes are lowest, who may have dropped out of the labour force, and (in Australia in particular) are 
unemployed, and who may therefore have had no option but to sell up to clear outstanding debts and meet pressing spending needs. It is, of course, possible that some sales among younger people are sales of properties they have inherited but are unable to retain, in light of running costs or other financial commitments. But whatever the route into ownership, it is clear that selling up is no longer simply about the transition to older age (whether to cover the costs of residential care or to add to pensions). It appears also to be about meeting the outgoings incurred by households in financial distress - an expensive and disruptive way of exchanging the costs of owning for those of renting.

[Figure 6]

The household patterning of equity withdrawal through trading on is quite similar to that associated with selling up, except that it seems less open to younger households. It is a route to equity extraction for those who are older, widowed, separated or not in the labour market; those with no dependent children are also prevalent, especially in Australia. Although some of these equity extractions are associated with trading up (to reiterate, around two in five of those who extracted equity through trading on in this study also moved to a higher-priced home) the majority of episodes are engaged in by households who we might expect to be encountering pressing spending needs - needs which, for the moment, can be met by downsizing rather than by exiting owner occupation.

\section{[Figure 7]}

The charts for in situ equity borrowing, shown as Figure 7, are almost the mirror image of those for the other styles of equity extraction. These episodes are disproportionately accounted for by households who are middle aged, married, have dependent children and are in the full or part-time labour market. Equity borrowers have the highest mean incomes of all equity extractors; they are higher too than those of equity savers. Furthermore, their borrowing capacity enables them to add significantly to their incomes on a year-by-year basis. Equity borrowing thus appears to be the middle-aged, middle income norm; a popular and effective means of using mortgage debt to bring forward spending or redistribute incomes across the life course. It is possible that equity borrowing in this context has a portfolio balancing function - something we have considered empirically elsewhere (Wood et al. in press). It is not clear, however, that many households would find a rate of return sufficiently higher than an additional property to offset the added leverage; and when equity borrowing funds second homes, there may be drivers other than portfolio balancing that dominate. Whatever the motivation, when compared to the personal and financial circumstances of other equity extractors, equity borrowers seem relatively well-positioned. 
However, in related studies, we have examined these equity borrowing behaviours more closely, comparing them not with those who sell up or move on, but with those who pay down their mortgage rather than add to their leverage. That is we compare equity borrowers with equity savers, matching the timing of equity borrowing with that of other life events and household transitions (Parkinson et al. 2009; Searle 2011; Wood et al., in press). The findings from this part of the wider analysis suggest that, far from funding a round of exuberant consumption, equity borrowings are used to meet pressing spending needs, and to manage life events that are conventionally uninsurable (such as separation, or the needs of schoolaged children, or the anticipation of financial stress). Furthermore, although such borrowings tend to fill spending gaps that are potentially bridgeable, these gaps can widen over time, making the whole exercise potentially risky for households' financial fortunes (Smith 2012).

\section{[Figure 8]}

We return to this wider context in the conclusion. For now, we note that the emerging 'safety net' role for housing wealth, even among equity borrowers, puts the evidence summarized in Figure 8 in a rather chilling light. Taking some key (inevitably slightly different) questions from each national survey, this figure links the different channels of HEW to varied measures of financial distress. The pattern is the same across every measure for both countries.

Without exception, the lowest incidence of financial distress is reported by those who, in the following year, did not engage in HEW. They experienced no pressing spending needs; they did not draw from their housing wealth. Somewhat higher rates of distress were present in the years preceding episodes of equity extraction. The pattern is much the same - let us call it moderate - for equity borrowing as for trading on, although some measures of distress (being unable to pay utility bills, needing help from family or friends, or feeling deprived relative to others) seem most salient in relation to equity borrowing. The real difference between equity borrowing and trading, however, might be the fact that higher incomes place equity borrowers in a better position, in the short term, to create a financial buffer by increasing their mortgage debt.

The incidence of financial distress is most marked of all among those who, within a year of reporting it, had sold up. This group has lower incomes than any other, and it is hard to resist the conclusion that some of them, at least, cashed in their home as a last financial resort. Wood and Ong (2012) show that almost 1.65 million spells of owner occupation in Australia ended between 2001 and 2009. Just under half failed to regain homeownership by during the study period. Evidence in Wood et al. (2010b) suggests further that the more durable transitions out of homeownership are primarily a result of financial stress and relationship breakdowns; they are matter of constraint rather than choice. 


\section{Conclusion}

There has been surprisingly little debate on the role, relevance and relative importance of the different channels from housing wealth to consumption. Such discussion as there is focuses on the resilience of whole economies, and is therefore concerned primarily with: the difference between indirect and direct transmission mechanisms; the distinction between borrowing up and selling on to raise funds; and whether the sums extracted are spent, saved or reinvested into property. All of this is important. However, rather little research casts light on the behaviours and budgetary tactics underpinning the household decisions that drive these processes. To be sure, there has been a flurry of interest in changing attitudes to inheritance, and in the interchangeability of housing wealth and pensions. However, one of the striking findings of the analysis here is that housing wealth is cashed in, or borrowed against, with some regularity, across the life course, and in sums far too large to ignore. The story of housing wealth is no longer about accumulating assets over the life course or managing the transition to older age; it is very much about the needs and tactics of households of all ages and stages, and in a variety of circumstances.

To tease out that wider narrative, we have examined three channels between housing wealth and consumption, capturing not only some well-rehearsed patterns of HEW through selling up or trading down, but also the less well-understood practice of MEW, both in situ, and through over-mortgaging or equity downsizing during residential relocation. The surprise, perhaps, is the prominence of in situ equity borrowing: its frequency and its magnitude, both for individuals and for the wider economy.

The findings also cast light on the relationship between equity borrowing and the other channels of equity extraction. Traditionally, these channels have been thought of independently: one group borrows up (those with earned incomes), while another sells on (those old enough to be outright owners with significant housing reserves). However, the data presented in this paper suggest that, in practice, such distinctions are hard to sustain. It is true that equity borrowing is limited to those whose incomes and other circumstances allow them to service a loan. But such borrowing occurs across the age range of the sample; as do the alternatives

Disney's (2009) position is that these channels are interchangeable in principle, but that this is hampered by failures in the equity downsizing market. People who enter a spiral of equity borrowing would, from this perspective, trade down and reduce (or pre-empt) unsustainable debts if the transactions costs of moving were less high. Furthermore, if transactions costs were channel-neutral we would, on this argument, see a different life course pattern, 
especially for those approaching (or in) retirement. That is, older people would downsize more often, consistent with a life cycle model of wealth accumulation and depletion.

Another possibility, more consistent with the analysis here, is that the channels are linked in a different way - in a chain of financial buffering for cash (liquidity)-constrained households with limited safety nets. This might suggest that the growing potential for HEW has mobilized Skinner's (1996) precautionary savings model for housing wealth. Certainly it is consistent with Benito's $(2007,2009)$ studies of MEW, and with related analyses of the drivers of equity borrowing (Parkinson et al. 2009).

However, there is a fourth interpretation suggested by our findings, namely that not only are the channels of equity withdrawal interchangeable, but that households move between them systematically, in what, for many, has the potential to become an unsustainable trajectory. This trajectory represents the ongoing 'mining' of housing wealth to meet pressing spending needs. Trading down or selling up are not, from this perspective, a neutral alternative to equity borrowing; they are a last resort when in situ options are exhausted. There is a precautionary savings, and indeed a market failure, dimension to this. However, we prefer to think of it as a 'welfare-switching' model for HEW (Smith 2012; Wood et al. 2012), in which equity borrowing is the first in a cascade of equity extractions effected to manage pressing spending needs arising from financial shocks. If there is a shift from channel to channel, it is thus likely to reflect a real wealth or income gap, as much as a call on precautionary savings or a turn in the life cycle. Institutional differences in housing markets aside, the similarities of financial regimes and regulations, and in the challenges of social policy, mean that in both Britain and Australia the various channels from housing wealth to consumption are together implicated in a switch away from collective insurances and towards more individualized (housing) asset-based welfare

\section{Acknowledgement \& Disclaimer}

The research for this paper was funded under the international collaboration scheme of the Australian Research Council (LX 0775767) and the UK's Economic and Social Research Council (RES-000-22-1985). The paper uses unit record data from: HILDA, initiated and funded by the Australian Government Department of Families, Housing, Community Services and Indigenous Affairs (FaHCSIA), and managed by the Melbourne Institute of Applied and Economic and Social Research (MIAESR); and BHPS, originally collected by the ESRC Research Centre on Micro-Social Change at the University of Essex and made available through the Economic and Social Research Council (ESRC) Data Archive. The findings and views reported in this paper are those of the authors. 


\section{References}

Ando, A. and Modigliano, F. (1963) The 'life cycle' hypothesis of saving. American Economic Review 53: 55-84.

Agarwal, S. (2007) The Impact of Homeowners' Housing Wealth Misestimation on Consumption and Saving Decisions. Real Estate Economics, 35 (2), 135-54.

Attanasio, O., Blow, L., Hamilton, R. \& Leicester, A. (2005) Consumption, house prices and expectations. Bank of England Working Paper 271

Attanasio, O. P. and Weber, G. (2010) 'Consumption and saving: Models of intertemporal allocation and their implications for public policy, Journal of Economic Literature, 48(3), 693-751.

Ball, M., Blanchette, R., Nanda, A. and Wyatt, P. (2011) Housing markets and independence in old age: expanding the opportunities. Henley Business School.

Benito, A. (2007) Housing Equity as a Buffer: Evidence from UK Households, Bank of England Working Paper 324.

Benito, A. (2009) Who withdraws housing equity and why?, Economica, 76, 51-70.

Bostic, R., Gabriel, S. and Painter, G. (2006) Housing wealth, financial wealth and consumption. New evidence from micro-data. Presented to the American Real Estate Association, Boston, January

Bridges, S., Disney, R. and Henley, A. (2006), Housing wealth and the accumulation of financial debt: evidence from UK households, in G. Bertola, R. Disney and C. Grant (eds.), The Economics of Consumer Credit, Cambridge, MA: MIT Press. Bucks, B, and Penns, K. (2006), Do Homeowners Know Their House Values and Mortgage Terms?, Finance and Economics Discussion Series 2006-3. Washington DC: Federal Reserve Board of Governors

Carroll, C. D., Otsuko, M. and Slacalek, J. (2011) How large are housing and financial wealth effects? A new approach. J. Money, Credit and Banking 43: 55-79 Case, K. E., Quigley, J. and Shiller, R. (2005), 'Comparing wealth effects: the stock market versus the housing market', Advances in Macroeconomics, 5(1), article 1. Disney, R. (2009), Australia: Issues in the Tax Treatment of Pensions and Housing, Presented at the Conference Australia's Future Tax System, Melbourne, 18-19 June. DiPasquale, D. and Somerville, C. T. (1995), Do house price indices based on transacting units represent the entire stock? Evidence from the American Housing Survey. Journal of Housing Economics, 4, 195-229

Doling, J. and Ronald, R. (2010), 'Home ownership and asset-based welfare', Journal of Housing and the Built Environment, 25, 165-173.

Duca, J. V., Muellbauer, J. and Murphy, A. (2010) Housing markets and the financial crisis of 2007-1009: lessons for the future. SERC Discussion Paper 49

Dvornak, N. and Kohler, M. (2007), 'Housing wealth, stock market wealth and consumption: A panel analysis for Australia', Economic Record, 83(261), 117-130. 
Ebner, A., 2010. A micro view on home equity withdrawal and its determinants.. Munich Discussion Paper No. 2010-2, Department of Economics, University of Munich German, Lord (ed) (2012) Making the most of equity release. London: Smith Institute Goodman, J.L. and J.B. Ittner. 1992. The Accuracy of Home Owners' Estimates of House Value. Journal of Housing Economics 2(4): 339-357

Greenspan, A. and Kennedy, J. (2007), Sources and Uses of Equity Extracted from Homes, Finance and Economics Discussion Series 2007-20 Divisions of Research \& Statistics and Monetary Affairs Federal Reserve Board, Washington, D.C.

Haffner, M. E. A. (2008), 'Savings for old age? Housing wealth of the Dutch elderly', Housing, Theory and Society, 25(2), 110-131.

Hamnett, C (1991) A nation of inheritors? Journal of Social Policy 20 (4): 509-36

Holmans, A. E. (2001), Housing and Mortgage Equity Withdrawal and their Component Flows London: Council of Mortgage Lenders.

Holmans, A. E. and Froszrega, M. (1997), Housing Equity Withdrawal, Occasional Paper, London: Department of the Environment.

Kennickell, A. B, and Starr-McCluer, M. (1997), Retrospective reporting of household wealth: Evidence from the 1983-1989 Survey of Consumer Finances, Journal of Business and Economic Statistics, 15(4), 452-63

Kim, K-H and Renaud, B. (2009) The global house price boom and its unwinding: an analysis and a commentary. Housing Studies 24: 7034

Lowe, S., Searle, B. A, and Smith, S. J. (2011) From housing wealth to mortgage debt: the emergence of Britain's asset-shaped welfare state. Social Policy and Society 11: 105-116

Muellbauer, J. (2012) Housing markets and the macroeconomy. In Smith SJ, 19 others (eds) The International Encyclopedia of Housing and Home. Elsevier.

Muellbauer, J. and Murphy, A. (2008) Housing markets and the economy: the assessment. Oxford Review of Economic Policy 24: 1-33.

Office for National Statistics (2009), Social Trends 40.

Parkinson, S. Searle, B. Smith, S. Stoakes, A. and Wood, G. (2009), 'Mortgage equity withdrawal in Australia and Britain: Toward a wealth-fare state?', European Journal of Housing Policy, 9(4), 365-389.

Poterba, J., Venti, S. and Wise, D. (2011), 'The composition and drawdown of wealth in retirement', Journal of Economic Perspectives, 25(4), 95-118.

Renaud, Bertrand and Kyung-Hwan Kim (2007) The global housing price boom and its aftermath. Housing Finance International, 22 (December): 2-15

Rowlingson, K. and McKay, S. (2005), Attitudes to Inheritance in Britain, Bristol:

Policy Press. 
Schwartz, C., Hampton, T., Lewis, C. and Norman, D. (2008) Factors Influencing Housing Equity Withdrawal: Evidence from a Microeconomic Survey, The Economic Record 84 (267) pp. 421-433

Searle B A (2011). Housing Wealth and Recession, Journal of Financial Economic Policy, 33, 1

Singer, J.D. and Willett, J. B. (2003), Applied Longitudinal Data Analysis; Modelling Change and Event Occurrence, Oxford University Press, Oxford

Skinner, J. S. (1996), 'Is housing wealth a side show?', In Advances in the Economics of Aging, edited by D. Wise, pp. 241-268. Chicago, IL: University of Chicago Press. Smith, S. J. (2012) 'Crisis and Innovation in the Housing Economy: A Tale of Three Markets' in Financial Innovation - Too Much or Too Little? Cambridge, Mass: MIT Press (M. Haliossis, ed)

Smith, S. J. and Searle, B. A. (2008), 'Dematerializing money: Observations on the flow of wealth from housing to other things', Housing Studies, 23, 21-43.

Smith, S. J., Ford, J. and Munro, M. (2002) A Review of Flexible Mortgages. Council of Mortgage Lenders Smith et al. 2008

Smith, S. J., Searle, B. A. and Cook, N. (2009) Rethinking the Risks of Owner Occupation. Journal of Social Policy 38: 83-102

Thorns, D. (1994) The role of housing inheritance in selected owner occupied societies. Housing Studies 9: 473-402

Turner, B and Yang, Z. (2006) Security of home ownership - using equity or benefiting from low debt? European journal of housing policy, 6 (3) pp. 279-296

Wood, G. and Nygaard, C. (2010), 'Housing equity withdrawal and retirement:

Evidence from the Survey of Household, Labour and Income Dynamics in Australia (HILDA)', In Smith, S. J. and Searle, B. A. (eds), The Housing Wealth of Nations, Oxford: Blackwell.

Wood, G., Colic-Peisker, V., Ong, R., Bailey, N. and Berry, M. (2010a), Housing Needs of Asset-Poor Older Australians: Other Countries' Policy Initiatives and their Implications for Australia, Positioning Paper No. 133, Melbourne: AHURI Wood, G., Colic-Peisker, V., Berry, M. and Ong, R. (2010b), Asset-Poverty and Older Australians' Transitions onto Housing Assistance Programs, Final Report No. 156, Melbourne: AHURI.

Wood, G. and Ong, R. (2012), Sustaining Homeownership in the $21^{\text {st }}$ Century; Emerging Policy Concerns, Final Report No. 187, Melbourne: AURI Wood, G., Parkinson, S., Searle, B. A. and Smith, S. J (2012) Motivations for Equity Borrowing: A Welfare Switching Effect. In review. 
Tables

Table 1: The potential for HEW among Owner Occupiers, 2001-08

\begin{tabular}{lcccccccc}
\hline \multirow{2}{*}{ Year } & \multicolumn{2}{c}{ Sell up cycles } & \multicolumn{2}{c}{ Trade on cycles } & \multicolumn{2}{c}{ In situ cycles } & \multicolumn{2}{c}{ Total } \\
\cline { 2 - 9 } & UK & Aus & UK & Aus & UK & Aus & UK & Aus \\
\hline $2001-2002$ & 33 & 118 & 227 & 190 & 4,764 & 3,946 & 5,024 & 4,254 \\
$2002-2003$ & 36 & 99 & 203 & 199 & 4,741 & 3,602 & 4,980 & 3,900 \\
$2003-2004$ & 46 & 92 & 197 & 132 & 4,645 & 3,454 & 4,888 & 3,678 \\
$2004-2005$ & 28 & 86 & 171 & 117 & 4,658 & 3,323 & 4,857 & 3,526 \\
$2005-2006$ & 33 & 81 & 196 & 129 & 4,670 & 3,284 & 4,899 & 3,494 \\
$2006-2007$ & 42 & 81 & 178 & 118 & 4,539 & 3,196 & 4,759 & 3,395 \\
$2007-2008$ & 19 & 84 & 89 & 84 & 4,463 & 3,146 & 4,571 & 3,314 \\
& & & & & & & & \\
Total & 237 & 641 & 1,261 & 969 & 32,480 & 23,951 & 33,978 & 25,561 \\
Row \% UK/Aus & 0.7 & 2.5 & 3.7 & 3.7 & 95.6 & 93.7 & 100 & 100 \\
\hline
\end{tabular}

Note: Counts refer to the number of owner-occupier households in the study during each year and for each activity; cell totals give the number of annual episodes potentially available for equity extraction Source: Authors' calculations (BHPS and HILDA)

Table 2: Equity withdrawal episodes, 2001-08, by channel

\begin{tabular}{|c|c|c|c|c|c|c|c|c|}
\hline \multirow[t]{3}{*}{ Year } & \multirow{2}{*}{\multicolumn{2}{|c|}{$\begin{array}{l}\text { Total number of } \\
\text { equity withdrawal } \\
\text { episodes }\end{array}$}} & \multicolumn{6}{|c|}{$\begin{array}{l}\text { Channel of equity withdrawal } \\
\text { (row \% of total equity withdrawal events) }\end{array}$} \\
\hline & & & \multicolumn{2}{|c|}{ Sell up } & \multicolumn{2}{|c|}{ Trade on } & \multicolumn{2}{|c|}{$\begin{array}{c}\text { In situ equity } \\
\text { borrowing }\end{array}$} \\
\hline & UK & Aus & UK & Aus & UK & Aus & UK & Aus \\
\hline 2001-2002 & 932 & 919 & 3 & 13 & 8 & 9 & 89 & 78 \\
\hline $2002-2003$ & 980 & 951 & 4 & 10 & 6 & 8 & 90 & 81 \\
\hline 2003-2004 & 921 & 816 & 5 & 11 & 6 & 6 & 89 & 83 \\
\hline 2004-2005 & 948 & 799 & 3 & 11 & 9 & 8 & 88 & 81 \\
\hline 2005-2006 & 887 & 771 & 4 & 11 & 9 & 8 & 87 & 81 \\
\hline 2006-2007 & 855 & 789 & 5 & 10 & 9 & 8 & 86 & 82 \\
\hline 2007-2008 & 728 & 684 & 3 & 12 & 7 & 8 & 91 & 80 \\
\hline Total (2001-8) & 6,251 & 5,729 & 4 & 11 & 8 & 8 & 89 & 81 \\
\hline
\end{tabular}

Source: Authors' calculations (BHPS and HILDA) 
Table 3: Aggregate values of housing equity withdrawal, annually, 2001-2008

\begin{tabular}{|c|c|c|c|c|c|c|c|c|}
\hline \multirow[t]{4}{*}{ Year } & \multicolumn{8}{|c|}{ Equity withdrawal channel } \\
\hline & \multicolumn{2}{|c|}{ Sell up } & \multicolumn{2}{|c|}{ Trade on } & \multicolumn{2}{|c|}{$\begin{array}{c}\text { In situ equity } \\
\text { borrowing }\end{array}$} & \multicolumn{2}{|c|}{ All channels } \\
\hline & UK & Aus & UK & Aus & UK & Aus & UK & Aus \\
\hline & $£ b n$ & \$bn & $£$ fbn & \$bn & $£$ bn & $\$ b n$ & fbn & \$bn \\
\hline 2001-2002 & 6.5 & 11.4 & 7.9 & 9.6 & 36.8 & 37.7 & 51.1 & 58.7 \\
\hline $2002-2003$ & 10.6 & 15.6 & 12.6 & 9.8 & 48.3 & 49.1 & 71.5 & 74.5 \\
\hline 2003-2004 & 9.2 & 14.8 & 18.6 & 7.9 & 52.1 & 51.2 & 80.0 & 74.0 \\
\hline 2004-2005 & 9.1 & 12.1 & 14.1 & 7.2 & 59.7 & 54.2 & 83.0 & 73.5 \\
\hline $2005-2006$ & 18.6 & 15.2 & 26.1 & 7.8 & 62.1 & 52.0 & 106.9 & 75.0 \\
\hline 2006-2007 & 22.0 & 12.3 & 9.6 & 8.9 & 58.8 & 59.8 & 90.4 & 80.9 \\
\hline 2007-2008 & 4.7 & 15.5 & 11.9 & 17.3 & 62.6 & 68.7 & 79.2 & 101.4 \\
\hline Total & 80.8 & 96.9 & 100.7 & 68.5 & 380.5 & 372.6 & 562.0 & 538.0 \\
\hline
\end{tabular}

Source: Authors' calculations (BHPS and HILDA)

Note: Population weighted data (see footnote 7)

Table 4: Ratio of median equity withdrawn to median gross household income, 2001-2008

\begin{tabular}{|c|c|c|c|c|c|c|c|c|}
\hline \multirow[t]{3}{*}{ Year } & \multicolumn{8}{|c|}{ Equity withdrawal } \\
\hline & \multicolumn{2}{|c|}{ Selling up } & \multicolumn{2}{|c|}{$\begin{array}{l}\text { Trading on equity } \\
\text { withdrawal }\end{array}$} & \multicolumn{2}{|c|}{$\begin{array}{c}\text { In situ equity } \\
\text { borrowing }\end{array}$} & \multicolumn{2}{|c|}{ All } \\
\hline & UK & Aus & UK & Aus & UK & Aus & UK & Aus \\
\hline 2001-2002 & 191.0 & 195.6 & 49.6 & 118.6 & 15.3 & 28.7 & 19.1 & 44.3 \\
\hline $2002-2003$ & 293.8 & 293.3 & 67.5 & 168.0 & 21.1 & 34.0 & 25.3 & 47.6 \\
\hline 2003-2004 & 323.3 & 354.0 & 108.5 & 197.8 & 28.8 & 41.0 & 29.6 & 48.1 \\
\hline 2004-2005 & 324.6 & 274.9 & 71.8 & 125.2 & 24.8 & 34.6 & 28.1 & 47.8 \\
\hline $2005-2006$ & 504.2 & 299.0 & 94.9 & 120.5 & 27.3 & 36.4 & 30.0 & 51.9 \\
\hline 2006-2007 & 489.6 & 247.6 & 65.2 & 153.3 & 23.5 & 33.2 & 27.1 & 47.5 \\
\hline $2007-2008$ & 437.7 & 281.5 & 172.8 & 174.6 & 23.5 & 36.7 & 25.4 & 50.8 \\
\hline Average & 345.5 & 267.9 & 82.4 & 147.1 & 22.4 & 33.8 & 28.6 & 48.2 \\
\hline
\end{tabular}

Source: Authors' calculations (BHPS and HILDA)

Note: Weighted data 
Table 5: Aggregate housing equity withdrawn in the economy as a percentage of gross household income in the economy, 2001-2008

\begin{tabular}{lcccccccc}
\hline & \multicolumn{2}{c}{ Selling up } & \multicolumn{2}{c}{ Trading on } & \multicolumn{2}{c}{ In situ equity } \\
borrowing & \multicolumn{2}{c}{ All channels } \\
\cline { 2 - 8 } Year & UK & Aus & UK & Aus & UK & Aus & UK & Aus \\
\hline $2001-2002$ & 1.0 & 2.5 & 1.2 & 2.1 & 5.7 & 8.4 & 8.0 & 13.0 \\
$2002-2003$ & 1.6 & 3.3 & 1.9 & 2.1 & 7.2 & 10.5 & 10.7 & 15.9 \\
$2003-2004$ & 1.3 & 3.0 & 2.7 & 1.6 & 7.5 & 10.2 & 11.5 & 14.8 \\
$2004-2005$ & 1.3 & 2.2 & 2.0 & 1.3 & 8.5 & 9.9 & 11.8 & 13.4 \\
$2005-2006$ & 2.6 & 2.6 & 3.7 & 1.3 & 8.7 & 8.7 & 14.9 & 12.6 \\
$2006-2007$ & 3.0 & 1.9 & 1.3 & 1.4 & 7.9 & 9.3 & 12.2 & 12.6 \\
$2007-2008$ & 0.6 & 2.2 & 1.5 & 2.5 & 8.0 & 9.8 & 10.1 & 14.5 \\
Total & 1.6 & 2.5 & 2.0 & 1.8 & 7.7 & 9.5 & 11.3 & 13.8 \\
\hline
\end{tabular}

Source: Authors' calculations (BHPS and HILDA); Office for National Statistics (2009), Social Trends 40, Note: The percentage for each channel is derived by dividing housing equity withdrawn (population weighted) via that channel by the gross income of all households in the economy

\section{Figures}

Figure 1. Median value of housing equity withdrawal, 2001-8

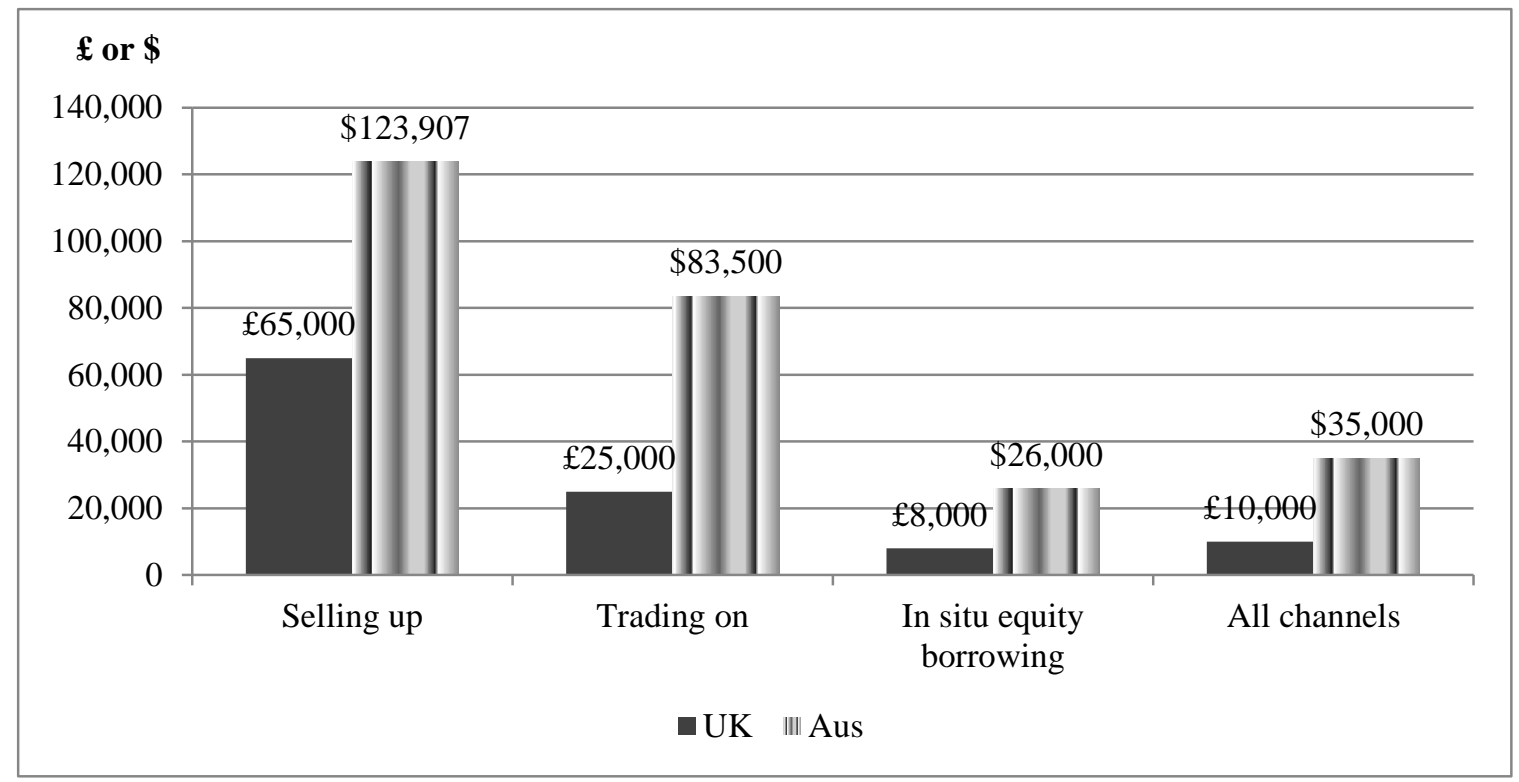

Source: Authors' calculations (BHPS and HILDA) 
Figure 2. Median values of housing equity withdrawal, annually, 2001-08



Source: Authors' calculations (BHPS and HILDA)

Figure 3. Aggregate housing equity withdrawal and injection, owner occupier households, total 2001-2008

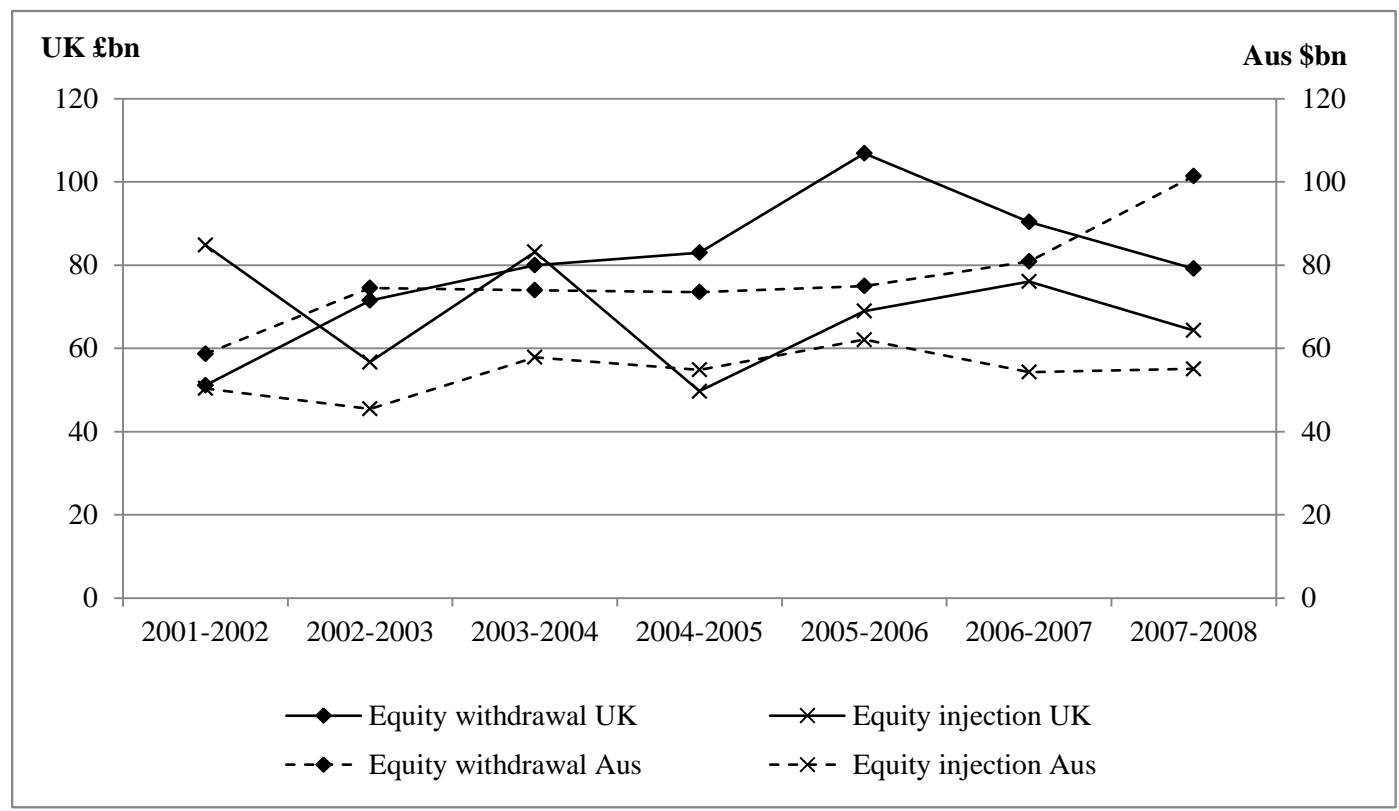

Source: Authors' calculations (BHPS and HILDA); Office for National Statistics (2009), Social Trends 40 
Figure 4. Median household income of equity extractors and savers, by channel, 2001-08

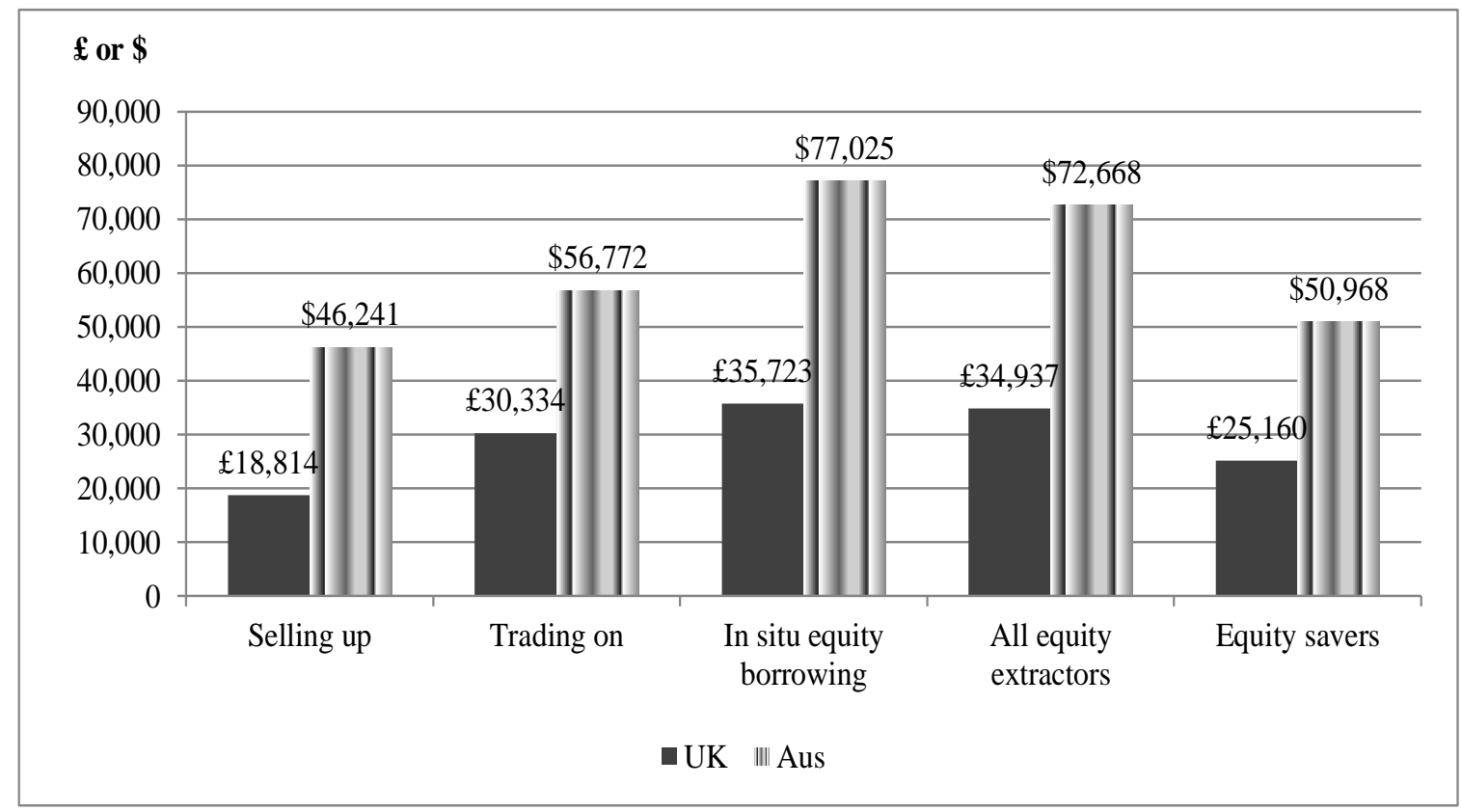

Source: Authors' calculations (BHPS and HILDA) 
Figure 5. Episodes of equity extraction on selling up, 2001-2008

(a) Sell up, UK

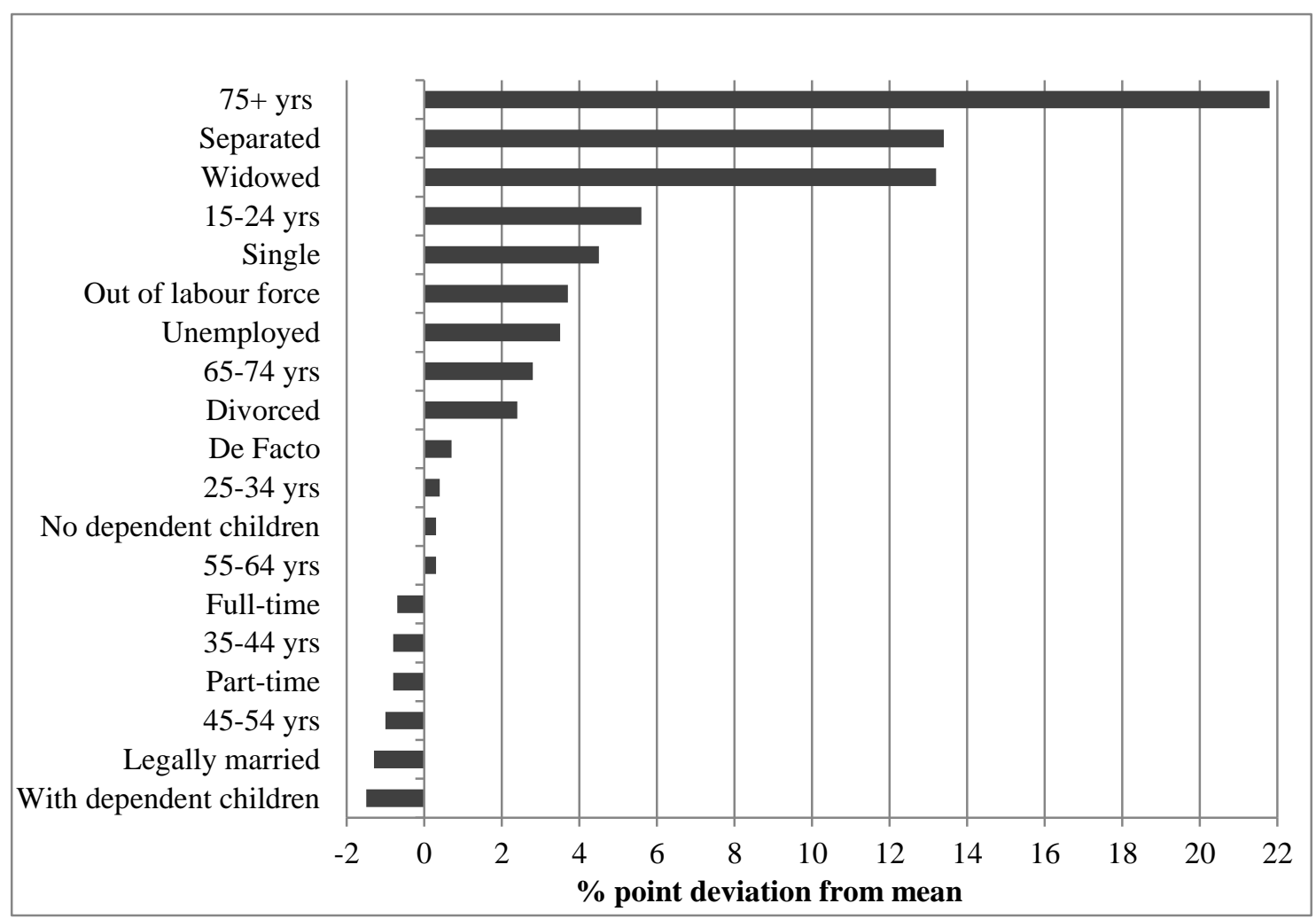

(b) Sell up, Australia

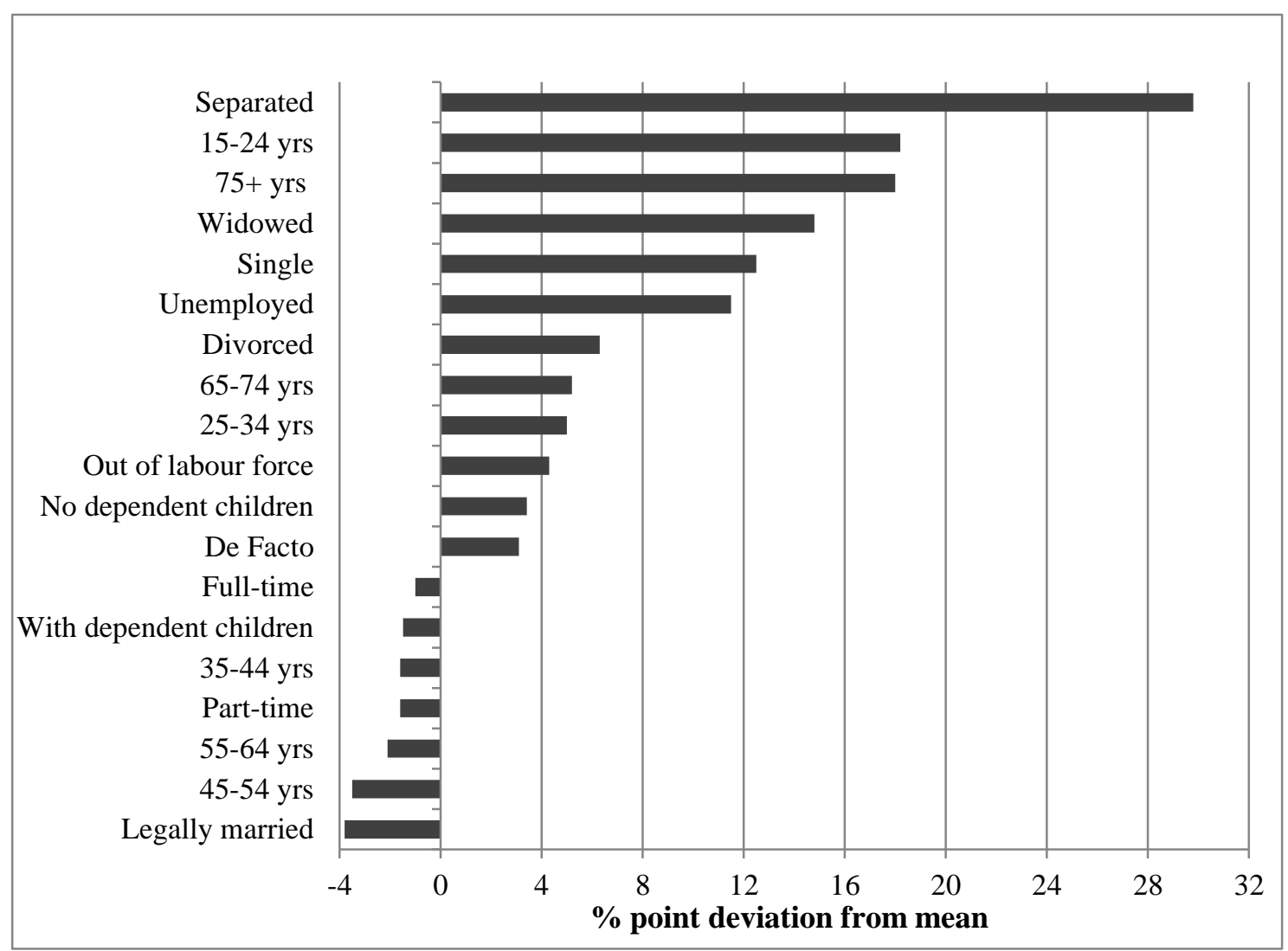


Figure 6 Episodes of equity extraction on trading on, 2001-2008

(a) Trade on, UK

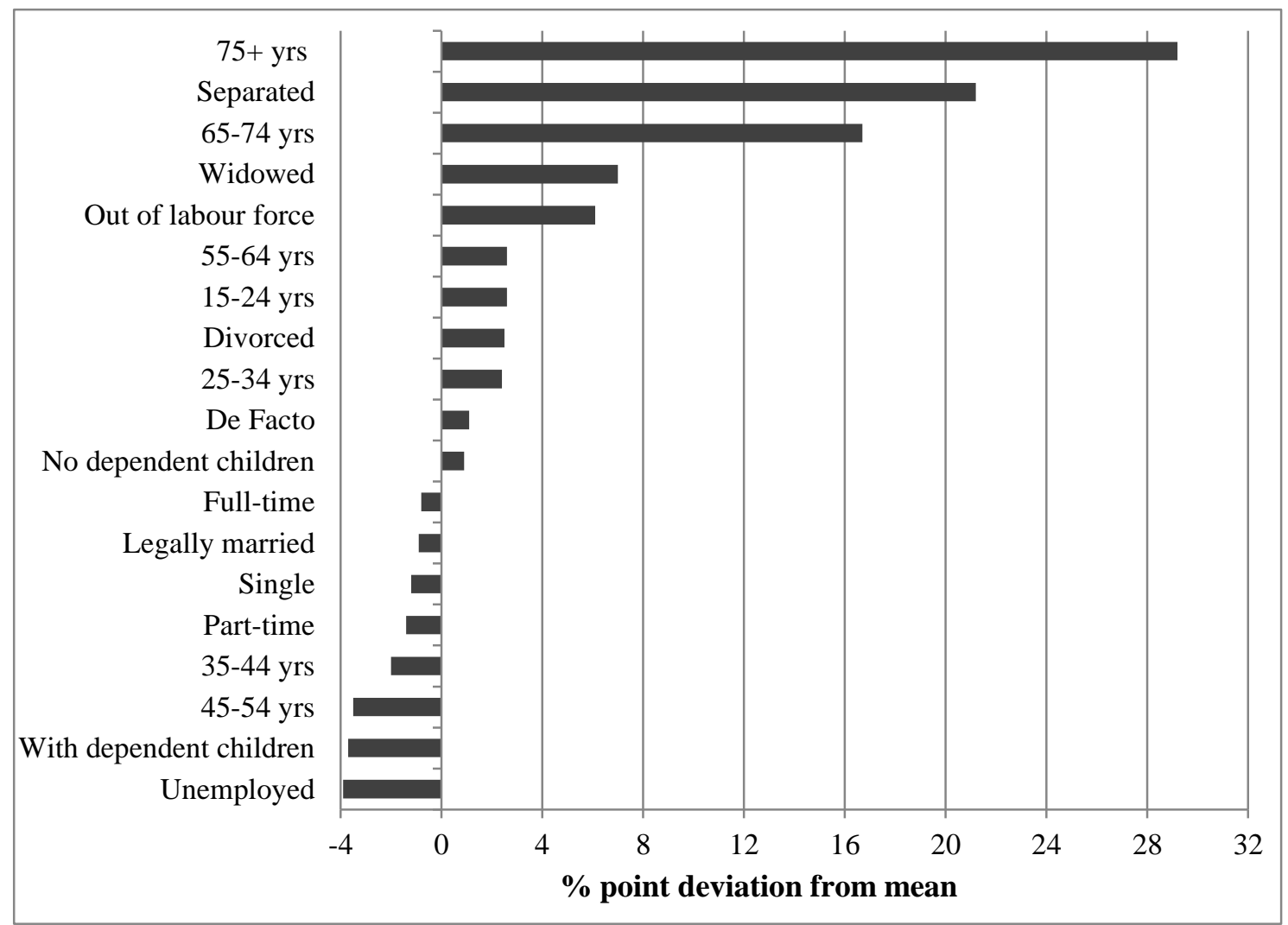

(b) Trade on, Australia

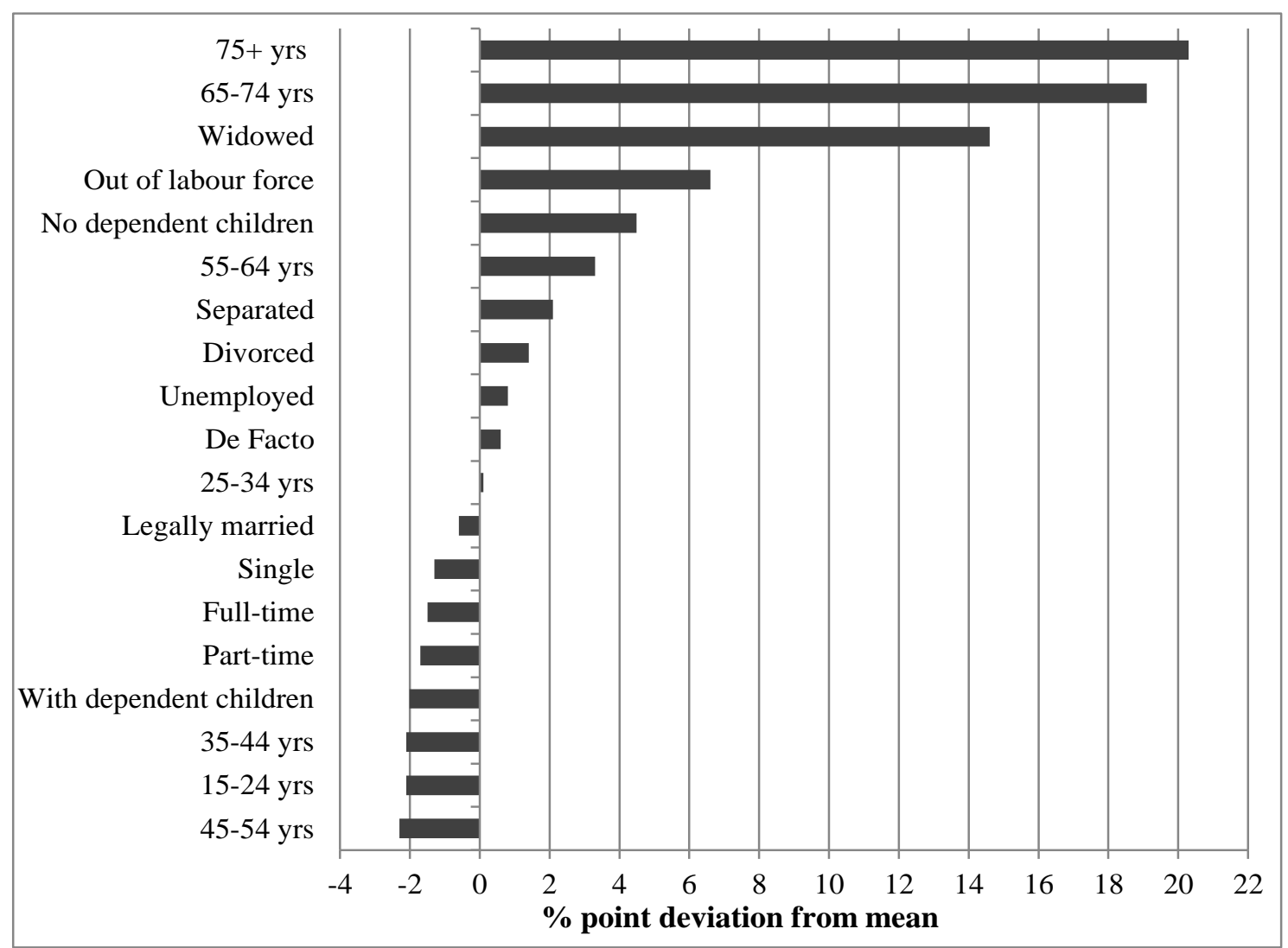


Figure 7. Episodes of equity extraction on in situ equity borrowing, 2001-2008

(a) In situ equity borrowing, UK

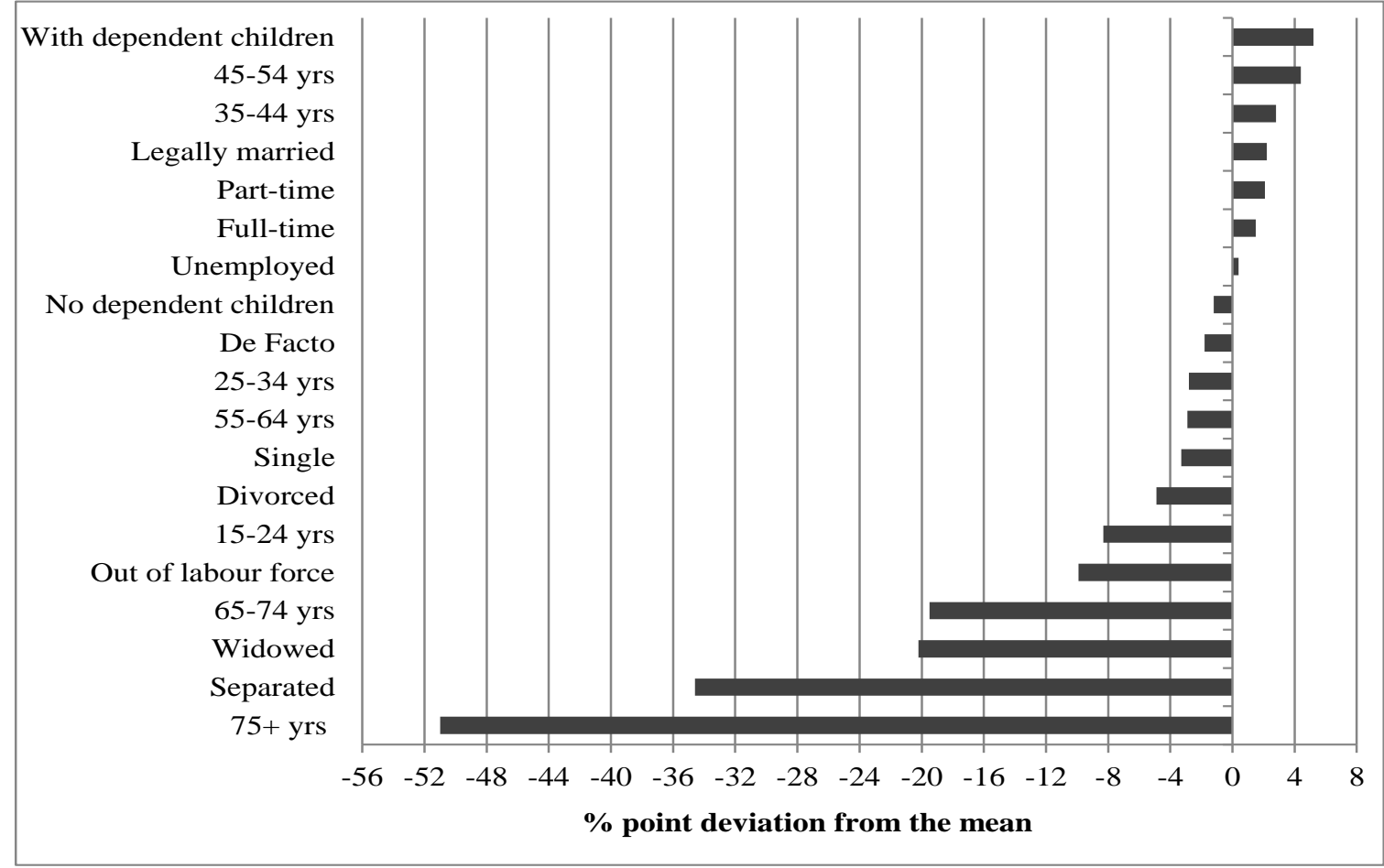

(b) In situ equity borrowing, Australia

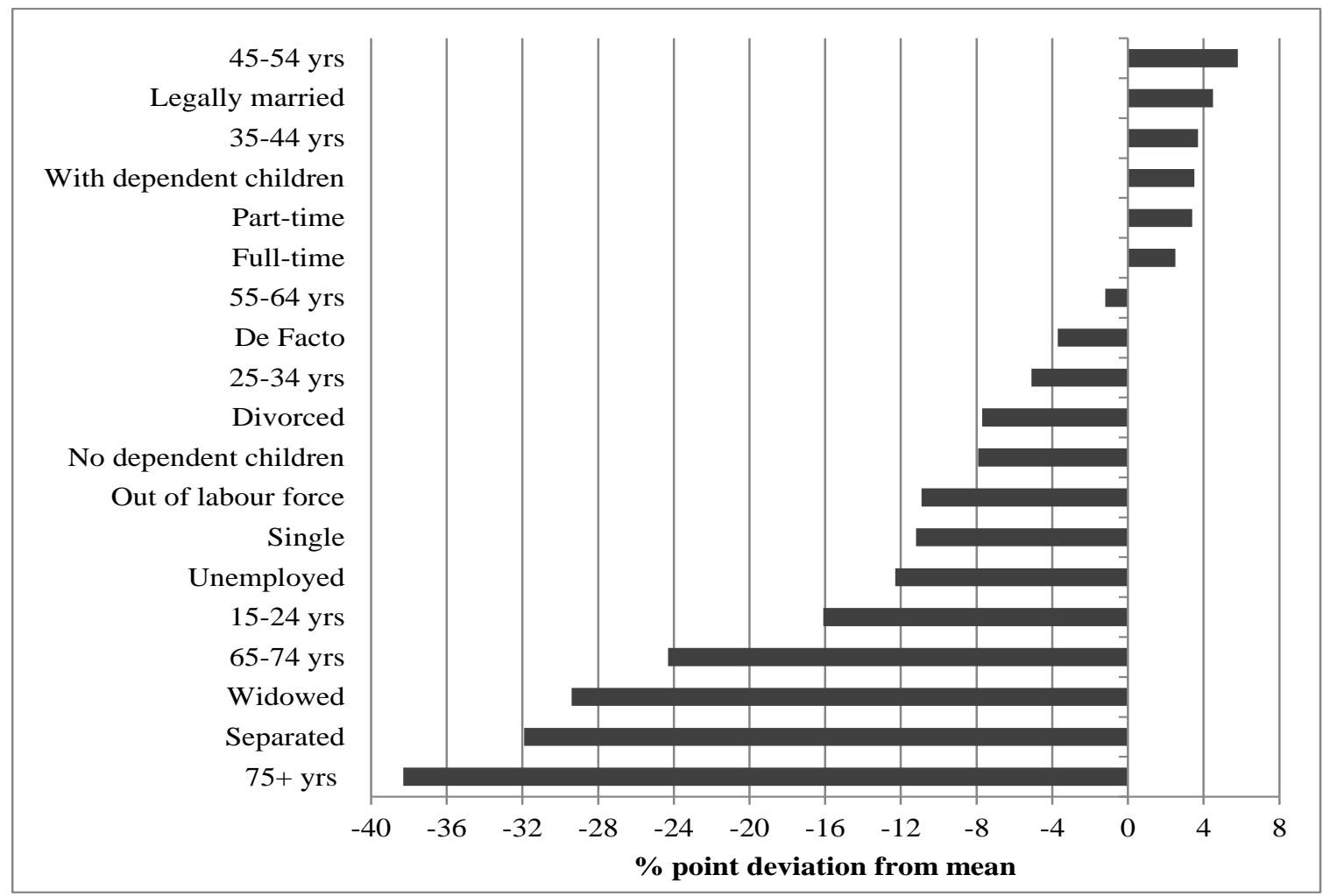

Source for Figures 5, 6 and 7: Authors' calculations (BHPS and HILDA)

Note for Figures 5, 6 and 7: Charts show the percentage deviation from the mean in the proportion of equity extraction cycles accounted for by different household types. 
Figure 8: Percentage within each channel of equity withdrawal who were in financial stress in the year prior to equity withdrawal, person-period episodes

(a) $\mathbf{U K}^{\mathbf{a}}$



\section{(b) Australia}

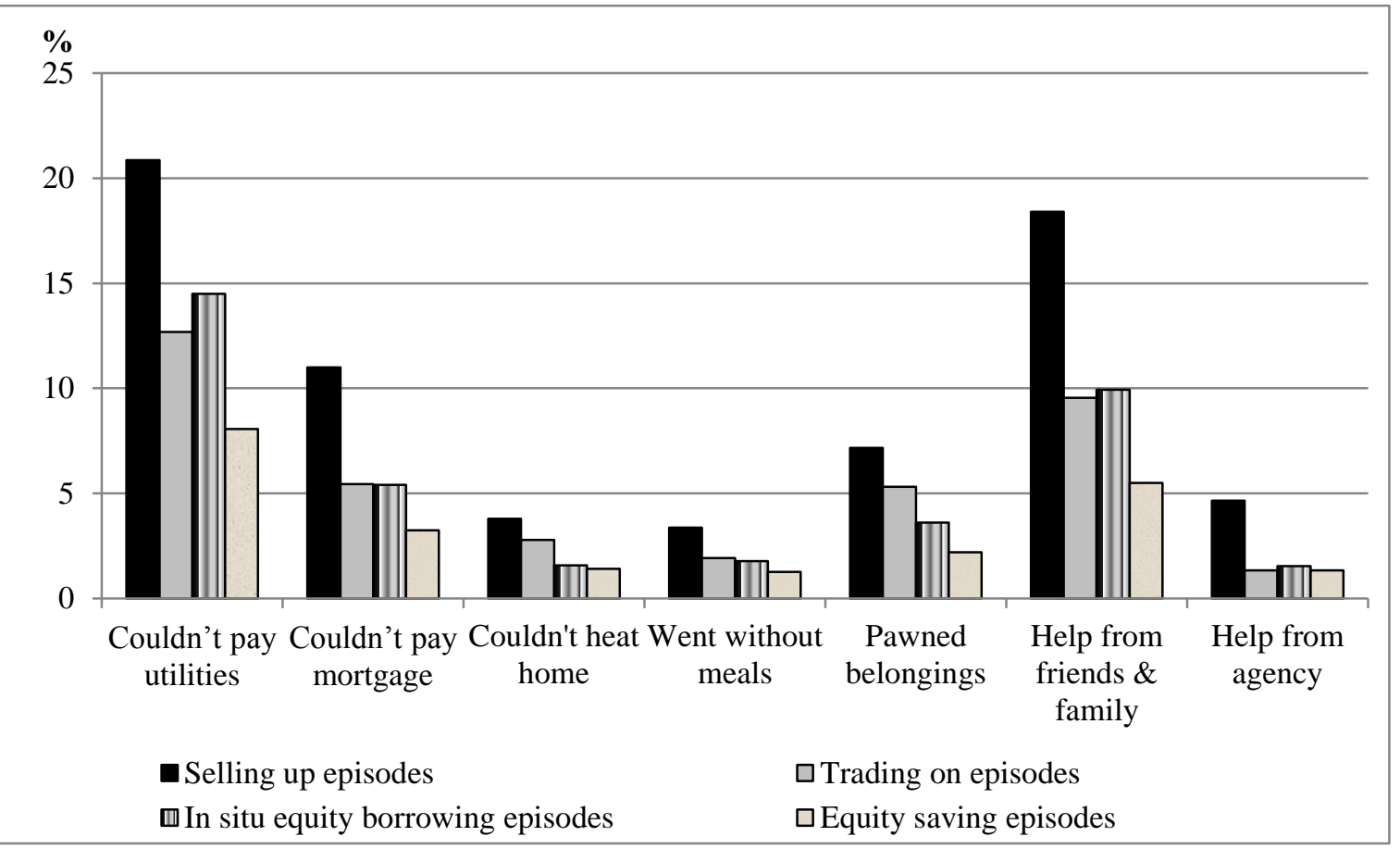

Source: Authors' calculations (BHPS and HILDA)

Note: Experiencing of relative material deprivation refers to difficulty keeping the home adequately warm, paying for a week's annual holiday away from home, replacing worn out furniture, buying new, rather than second hand, clothes, affording meat, chicken or fish at least every second day, or having visitors for a drink or meal at least once a month. 


\section{Appendix A}

Figures 5, 6 and 7 show the incidence of episodes of equity withdrawal among households with different characteristics. They represent the extent to which equity extraction through a given channel is disproportionately associated with particular individual or household attributes. This Appendix gives findings from a multivariate modeling exercise that explores this relationship. The conclusions are similar, but the results offer additional insights into the strength of the relationships between different socio-economic and demographic characteristics and mode of equity extraction.

\section{Methodology}

The aim is to estimate the likelihood of equity extraction for each channel as a function of the personal characteristics of equity extractors. There are 6 random effect logit models (one for each channel in each country) using the characteristics reported in figures 5, 6 and 7 as regressors. These characteristics are represented by a series of dummy variables, with regression coefficient estimates for each characteristic category defined by reference to an omitted category that is identified in the list below:

- With dependent children, without dependent children (omitted).

- Legally married (omitted), de facto, separated, divorced, widowed, single.

- Employed full-time, employed part-time, unemployed, not in the labour force (omitted).

- 15-24 years, 25-34 years, 35-44 years, 45-54 years, 55-64 years, 65+ years (omitted).

- Time dummies: 2001-02, 2002-03, 2003-04, 2004-05, 2005-06, 2006-07, 2007-08 (omitted). 
The sample (as in the figures) comprises episodes of equity extraction only; annual cycles with no equity extraction are ignored. The coefficient estimates are then conditional on equity extraction.

\section{Findings}

Results are presented in the form of odds ratio estimates in tables A.1, A.2 and A.3 below. These ratios refer to the odds of one type of person or household having engaged in equity extraction, compared to the likelihood of a person or household in the omitted category having done so. Using odds ratios gives the table entries an intuitive interpretation that is easier to grasp than raw coefficient estimates (Singer and Willet, 2003). For example, the likelihood of UK divorcees extracting equity by selling up (Table A.1) is over four and a half times greater than that of the omitted category, continuously married. This is represented by an odds ratio for divorced of 4.7 .

The models overall are statistically significant at the $1 \%$ level $(1,5$ and 10 per cent flags for individual odds ratios are given in the tables). The findings are consistent with those reported in the text: selling up and trading on are more likely to occur in the later stages of the life course, and the inclination to use these channels is particularly strong among those older persons that have experienced marital breakdown, or widowhood, and are not employed. In situ equity borrowing is much more probable among the employed middle-aged, particularly those legally married and with dependent children. 
Table A.1 : Odds of selling up as a function of key personal characteristics, 2001-2008

\begin{tabular}{|c|c|c|c|c|}
\hline Characteristics & UK & & Aus & \\
\hline \multirow[t]{2}{*}{ Dependent children present } & 0.960 & & 0.820 & $* *$ \\
\hline & $(0.190)$ & & $(0.082)$ & \\
\hline \multirow[t]{2}{*}{ De facto } & 2.865 & $* * *$ & 2.297 & $* * *$ \\
\hline & $(0.706)$ & & $(0.274)$ & \\
\hline \multirow[t]{2}{*}{ Separated } & 29.778 & $* * *$ & 18.530 & $* * *$ \\
\hline & (12.252) & & $(2.941)$ & \\
\hline \multirow[t]{2}{*}{ Divorced } & 4.731 & $* * *$ & 4.813 & $* * *$ \\
\hline & (1.581) & & $(0.754)$ & \\
\hline \multirow[t]{2}{*}{ Widowed } & 6.048 & $* * *$ & 4.092 & $* * *$ \\
\hline & $(2.605)$ & & $(0.934)$ & \\
\hline \multirow[t]{2}{*}{ Single } & 7.871 & $* * *$ & 4.159 & $* * *$ \\
\hline & (2.616) & & $(0.622)$ & \\
\hline \multirow[t]{2}{*}{ Employed full-time } & 0.298 & $* * *$ & 0.645 & $* * *$ \\
\hline & $(0.068)$ & & $(0.069)$ & \\
\hline \multirow[t]{2}{*}{ Employed part-time } & 0.319 & $* * *$ & 0.655 & $* * *$ \\
\hline & $(0.085)$ & & $(0.082)$ & \\
\hline \multirow[t]{2}{*}{ Unemployed } & 0.983 & & 1.634 & $* *$ \\
\hline & $(0.471)$ & & $(0.400)$ & \\
\hline \multirow[t]{2}{*}{$15-24$ years } & 0.990 & & 2.226 & $* * *$ \\
\hline & $(0.523)$ & & $(0.559)$ & \\
\hline \multirow[t]{2}{*}{ 25-34 years } & 0.474 & $*$ & 1.186 & \\
\hline & $(0.185)$ & & $(0.228)$ & \\
\hline \multirow[t]{2}{*}{$35-44$ years } & 0.264 & $* * *$ & 0.546 & $* * *$ \\
\hline & $(0.107)$ & & $(0.108)$ & \\
\hline \multirow[t]{2}{*}{$45-54$ years } & 0.255 & $* * *$ & 0.345 & $* * *$ \\
\hline & $(0.101)$ & & $(0.070)$ & \\
\hline \multirow[t]{2}{*}{$55-64$ years } & 0.437 & $* *$ & 0.391 & $* * *$ \\
\hline & $(0.164)$ & & $(0.077)$ & \\
\hline \multirow[t]{2}{*}{$2001-02$} & 1.080 & & 1.000 & \\
\hline & $(0.353)$ & & $(0.140)$ & \\
\hline \multirow[t]{2}{*}{$2002-03$} & 1.702 & $*$ & 0.901 & \\
\hline & $(0.519)$ & & $(0.124)$ & \\
\hline \multirow[t]{2}{*}{ 2003-04 } & 1.770 & $*$ & 1.009 & \\
\hline & $(0.540)$ & & $(0.139)$ & \\
\hline \multirow[t]{2}{*}{ 2004-05 } & 0.907 & & 1.024 & \\
\hline & $(0.303)$ & & $(0.141)$ & \\
\hline
\end{tabular}




\begin{tabular}{lrrrrl}
\hline $2005-06$ & 1.460 & 0.934 & \\
& $(0.460)$ & $(0.130)$ & \\
$2006-07$ & 2.208 & $* * *$ & 0.841 & \\
& $(0.682)$ & $(0.119)$ & \\
Constant & 0.019 & $* * *$ & 0.108 & $* * *$ \\
& $(0.009)$ & & $(0.020)$ & \\
\hline Wald Chi2(20) & 110.340 & $* * *$ & 498.63 & $* * *$ \\
P & 0.519 & & 0.192 & \\
\hline
\end{tabular}

Source: Authors' calculations (BHPS and HILDA)

Note: Standard errors are reported in parentheses. *** represents statistical significance at the $1 \%$ level, ** represents statistical significance at the 5\% level and * represents statistical significance at the $10 \%$ level. The omitted categories are Legally married, Out of labour force, 65 years or over, and 2007-08. The UK (Australian) sample comprises 9,604 $(11,636)$ person-period observations of equity extraction. In the BHPS, dependent children are defined as a child aged under 19 years old who live in the same household as the parent. Dependent children in HILDA are defined as a child under 15 years old or a single dependent student aged 15-24 years old who is studying full-time and lives with a parent in the same household. 
Table A.2 : Odds of trading on as a function of key personal characteristics, 2001-2008

\begin{tabular}{|c|c|c|c|c|}
\hline Characteristics & UK & & Aus & \\
\hline \multirow[t]{2}{*}{ Dependent children present } & 0.715 & $* * *$ & 0.639 & $* * *$ \\
\hline & $(0.078)$ & & $(0.065)$ & \\
\hline \multirow[t]{2}{*}{ De facto } & 1.243 & $*$ & 1.225 & $*$ \\
\hline & $(0.157)$ & & $(0.152)$ & \\
\hline \multirow[t]{2}{*}{ Separated } & 3.216 & $* * *$ & 1.524 & $* *$ \\
\hline & $(0.745)$ & & $(0.265)$ & \\
\hline \multirow[t]{2}{*}{ Divorced } & 1.992 & $* * *$ & 1.174 & \\
\hline & $(0.357)$ & & $(0.198)$ & \\
\hline \multirow[t]{2}{*}{ Widowed } & 2.308 & $* * *$ & 1.275 & \\
\hline & $(0.561)$ & & $(0.277)$ & \\
\hline \multirow[t]{2}{*}{ Single } & 0.683 & $*$ & 0.749 & \\
\hline & $(0.152)$ & & $(0.146)$ & \\
\hline \multirow[t]{2}{*}{ Employed full-time } & 0.659 & $* * *$ & 0.600 & $* * *$ \\
\hline & $(0.083)$ & & $(0.062)$ & \\
\hline \multirow[t]{2}{*}{ Employed part-time } & 0.647 & $* * *$ & 0.589 & $* * *$ \\
\hline & $(0.093)$ & & $(0.072)$ & \\
\hline \multirow[t]{2}{*}{ Unemployed } & 0.332 & $* *$ & 0.830 & \\
\hline & $(0.160)$ & & $(0.249)$ & \\
\hline \multirow[t]{2}{*}{$15-24$ years } & 0.424 & $* * *$ & 0.221 & $* * *$ \\
\hline & $(0.144)$ & & $(0.075)$ & \\
\hline \multirow[t]{2}{*}{$25-34$ years } & 0.467 & $* * *$ & 0.364 & $* * *$ \\
\hline & $(0.099)$ & & $(0.065)$ & \\
\hline \multirow[t]{2}{*}{$35-44$ years } & 0.238 & $* * *$ & 0.282 & $* * *$ \\
\hline & $(0.052)$ & & $(0.051)$ & \\
\hline \multirow[t]{2}{*}{$45-54$ years } & 0.132 & $* * *$ & 0.259 & $* * *$ \\
\hline & $(0.030)$ & & $(0.047)$ & \\
\hline \multirow[t]{2}{*}{ 55-64 years } & 0.382 & $* * *$ & 0.426 & $* * *$ \\
\hline & $(0.077)$ & & $(0.069)$ & \\
\hline \multirow[t]{2}{*}{$2001-02$} & 1.040 & & 1.233 & \\
\hline & $(0.179)$ & & $(0.175)$ & \\
\hline \multirow[t]{2}{*}{$2002-03$} & 0.902 & & 1.120 & \\
\hline & $(0.158)$ & & $(0.156)$ & \\
\hline \multirow[t]{2}{*}{ 2003-04 } & 0.853 & & 0.816 & \\
\hline & $(0.152)$ & & $(0.124)$ & \\
\hline \multirow[t]{2}{*}{ 2004-05 } & 1.500 & $* *$ & 1.132 & \\
\hline & $(0.246)$ & & $(0.159)$ & \\
\hline
\end{tabular}




\begin{tabular}{lrrrl}
\hline $2005-06$ & 1.500 & $* *$ & 1.145 & \\
& $(0.249)$ & & $(0.160)$ & \\
$2006-07$ & 1.370 & $*$ & 1.075 & \\
& $(0.232)$ & $(0.151)$ & \\
Constant & 0.260 & $* * *$ & 0.331 & $* * *$ \\
& $(0.052)$ & & $(0.051)$ & \\
\hline Wald Chi2(20) & 270.30 & $* * *$ & 296.41 & $* * *$ \\
$\rho$ & 0.133 & & 0.159 & \\
\hline
\end{tabular}

Source: Authors' calculations (BHPS and HILDA)

Note: Standard errors are reported in parentheses. *** represents statistical significance at the $1 \%$ level, ** represents statistical significance at the $5 \%$ level and * represents statistical significance at the $10 \%$ level. The omitted categories are Legally married, Out of labour force, 65 years or over, and 2007-08. The UK (Australian) sample comprises 9,604 $(11,636)$ person-period observations of equity extraction. In the BHPS, dependent children are defined as a child aged under 19 years old who live in the same household as the parent. Dependent children in HILDA are defined as a child under 15 years old or a single dependent student aged 15-24 years old who is studying full-time and lives with a parent in the same household. 
Table A.3: Odds of in situ equity borrowing as a function of key personal characteristics, 2001-2008

\begin{tabular}{|c|c|c|c|c|}
\hline \multirow{2}{*}{$\begin{array}{l}\text { Characteristics } \\
\text { Dependent children present }\end{array}$} & \multicolumn{2}{|l|}{$\mathbf{U K}$} & \multicolumn{2}{|l|}{ Aus } \\
\hline & 1.302 & $* * *$ & 1.461 & $* * *$ \\
\hline & $(0.128)$ & & $(0.120)$ & \\
\hline \multirow[t]{2}{*}{ De facto } & 0.640 & $* * *$ & 0.534 & $* * *$ \\
\hline & $(0.074)$ & & $(0.053)$ & \\
\hline \multirow[t]{2}{*}{ Separated } & 0.121 & $* * *$ & 0.083 & $* * *$ \\
\hline & $(0.024)$ & & $(0.011)$ & \\
\hline \multirow[t]{2}{*}{ Divorced } & 0.377 & $* * *$ & 0.327 & $* * *$ \\
\hline & $(0.062)$ & & $(0.044)$ & \\
\hline \multirow[t]{2}{*}{ Widowed } & 0.255 & $* * *$ & 0.337 & $* * *$ \\
\hline & $(0.061)$ & & $(0.069)$ & \\
\hline \multirow[t]{2}{*}{ Single } & 0.610 & $* * *$ & 0.414 & $* * *$ \\
\hline & $(0.103)$ & & $(0.055)$ & \\
\hline \multirow[t]{2}{*}{ Employed full-time } & 1.981 & $* * *$ & 1.791 & $* * *$ \\
\hline & $(0.224)$ & & $(0.155)$ & \\
\hline \multirow[t]{2}{*}{ Employed part-time } & 1.959 & $* * *$ & 1.778 & $* * *$ \\
\hline & $(0.254)$ & & $(0.179)$ & \\
\hline \multirow[t]{2}{*}{ Unemployed } & 1.737 & $*$ & 0.772 & \\
\hline & $(0.553)$ & & $(0.168)$ & \\
\hline \multirow[t]{2}{*}{ 15-24 years } & 1.997 & $* *$ & 1.418 & \\
\hline & $(0.586)$ & & $(0.319)$ & \\
\hline \multirow[t]{2}{*}{ 25-34 years } & 2.472 & $* * *$ & 2.038 & $* * *$ \\
\hline & $(0.490)$ & & $(0.327)$ & \\
\hline \multirow[t]{2}{*}{$35-44$ years } & 4.851 & $* * *$ & 3.860 & $* * *$ \\
\hline & $(0.996)$ & & $(0.623)$ & \\
\hline \multirow[t]{2}{*}{$45-54$ years } & 7.552 & $* * *$ & 5.279 & $* * *$ \\
\hline & $(1.575)$ & & $(0.864)$ & \\
\hline \multirow[t]{2}{*}{$55-64$ years } & 2.948 & $* * *$ & 3.490 & $* * *$ \\
\hline & $(0.565)$ & & $(0.537)$ & \\
\hline \multirow[t]{2}{*}{ 2001-02 } & 0.931 & & 0.923 & \\
\hline & $(0.146)$ & & $(0.104)$ & \\
\hline \multirow[t]{2}{*}{$2002-03$} & 0.904 & & 1.019 & \\
\hline & $(0.140)$ & & $(0.112)$ & \\
\hline \multirow[t]{2}{*}{ 2003-04 } & 0.922 & & 1.114 & \\
\hline & $(0.144)$ & & $(0.127)$ & \\
\hline \multirow[t]{2}{*}{ 2004-05 } & 0.720 & $* *$ & 0.934 & \\
\hline & $(0.110)$ & & $(0.103)$ & \\
\hline
\end{tabular}




\begin{tabular}{lrlrl}
\hline $2005-06$ & 0.645 & $* * *$ & 0.977 & \\
& $(0.098)$ & & $(0.108)$ & \\
$2006-07$ & 0.620 & $* * *$ & 1.071 & \\
& $(0.095)$ & & $(0.119)$ & \\
Constant & 2.641 & $* * *$ & 1.472 & $* * *$ \\
& $(0.489)$ & & $(0.203)$ & \\
\hline Wald Chi2(20) & 364.05 & $* * *$ & 668.09 & $* * *$ \\
$\rho$ & 0.185 & & 0.235 & \\
\hline
\end{tabular}

Source: Authors' calculations (BHPS and HILDA)

Note: Standard errors are reported in parentheses. *** represents statistical significance at the $1 \%$ level, ** represents statistical significance at the $5 \%$ level and $*$ represents statistical significance at the $10 \%$ level. The omitted categories are Legally married, Out of labour force, 65 years or over, and 2007-08. The UK (Australian) sample comprises 9,604 $(11,636)$ person-period observations of equity extraction. In the BHPS, dependent children are defined as a child aged under 19 years old who live in the same household as the parent. Dependent children in HILDA are defined as a child under 15 years old or a single dependent student aged 15-24 years old who is studying full-time and lives with a parent in the same household. 